\title{
A Standing Framework for Private EXTRATERritorial ANTITRUST ENFORCEMENT
}

\author{
Max Huffman*
}

\section{INTRODUCTION}

7 HE attractions of the U.S. forum for foreign plaintiffs; the sophistication of the U.S. class-action bar; steadily and rapidly increasing global economic interdependence; and instant around-the-world communication have combined to bring foreign plaintiffs in ever-increasing numbers into U.S. courts. ${ }^{1}$ Nowhere is this reality more apparent than in the antitrust arena. ${ }^{2}$ The U.S. system promises "jury trials, wideranging pretrial discovery without judicial supervision ...., extraterritorial discovery, treble damages, class actions, [and] contingent fees." ${ }^{3}$ These

* Visiting Assistant Professor, University of Cincinnati College of Law (2005-2007). Thanks will always be due to Richard R. Huffman, for his lifelong mentorship. Thanks also to Roy T. Englert, Jr., and Donald J. Russell for early guidance and inspiration on this topic; to my wife Patricia V. Galvan, my mother Letha Schwiesow, Darren Bush, Christopher Musillo, Donna Nagy, and Michael Van Alstine for invaluable comments on drafts of this article; and to my colleagues at the University of Cincinnati for thoughts on my analysis. Research assistance provided by Don Blair of the U.C. Law Library faculty and Ryan Kelsey, U.C. Law Class of 2008. All opinions and errors are my responsibility.

1. See, e.g., Piper Aircraft Corp. v. Reyno, 454 U.S. 235 (1981) (forum non conveniens decision rejecting effort to sue in U.S. court under U.S. tort laws over an airplane crash that occurred in Scotland); Smith Kline \& French Labs, Ltd. v. Bloch, 1 W.L.R. 730 (C.A. 1982) (Lord Denning) ("As a moth is drawn to the light, so is a litigant drawn to the United States. If he can only get his case into their courts, he stands to win a fortune."); Lily Henning, Antitrust Goes Global: D.C. Circuit Opens the Door to Foreign Victims of Vitamin Price Fixing, Legal Times, Oct. 13, 2003, at 1 ("Already, some lawyers have begun to cast their nets for clients, hopping planes to places as far afield as the Czech Republic to look for purchasers who bought vitamins from cartel members."); $c f$. Ellen S. Podgor, A New Dimension to the Prosecution of White Collar Crime: Enforcing Extraterritorial Social Harms, 37 McGeorge L. Rev. 83, 94 (2006) (citing considerations of "increased travel, commerce, and accessibility to communicate with other countries").

2. Cf. Ellen S. Podgor, "Defensive Territoriality": A New Paradigm for the Prosecution of Extraterritorial Business Crimes, 31 GA. J. InT'L \& Comp. L. 1, 20 (2002) ("The most noticeable business crimes area with cases extending jurisdiction beyond the borders of the United States is in the area of antitrust.") (citing United States v. Nippon Paper Indus. Co., 109 F.3d 1 (1st Cir. 1997)); cf. id. at 17 (arguing that challenges associated with globalization are unique to business crimes and torts).

3. Joseph P. Griffin, Foreign Governmental Reactions to U.S. Assertions of Extraterritorial Jurisdiction, 6 Geo. Mason L. Rev. 505, 516 (1998). See also, e.g., Herbert Hovenkamp, The Antitrust Enterprise: Principle and Execution 63 (2005) (noting the uniqueness to the U.S. system of trials by lay juries in antitrust actions); Geoffrey C. Hazard, Discovery and the Role of the Judge in Civil Law Jurisdictions, 73 Notre Dame L. REV. 1017, 1017, 1018-19 (1998) (noting the lack of an available pre-trial discovery in civil law jurisdictions). With specific regard to the treble damages remedy, "the United States 
features-as well as the very existence of the private action itself, which is more limited or entirely lacking in many foreign jurisdictions ${ }^{4}$ - combine to create "a multi-color brochure for international antitrust tourism."

Efforts by private plaintiffs to enforce the U.S. antitrust laws extraterritorially have become an enormous industry. The effects of those efforts may be positive for those private plaintiffs who are successful, but they threaten significant consequences for other plaintiffs, for defendants, and for federal courts now faced with worldwide class actions and the attendant procedural difficulties. Defendants' calculus of litigation risk must undergo wholesale revision. And extraterritorial enforcement efforts threaten consequences for public enforcement and for international relations that are only beginning to be understood. ${ }^{6}$

... is the only country, except for Taiwan, which provides for punitive damages in addition to actual damages incurred by the plaintiff." Margaret Levenstein \& Valerie Y. Suslow, Contemporary International Cartels and Developing Countries: Economic Effects and Implications for Competition Policy, 71 AnTiTrust L.J. 801, 845 (2004). But see Wolfgang Wurmnest, Foreign Private Plaintiffs, Global Conspiracies and the Extraterritorial Application of U.S. Antitrust Law 28 Hastings InT'L \& Comp. L. Rev. 205, 222 (2005) (stating that Panama's Competition Act permits treble damages for private plaintiffs).

4. See HovenKamp, supra note 3 , at 59.

5. Makan Delrahim, Deputy Assistant Attorney Gen., U.S. Dep’t of Justice, Department of Justice Perspectives on International Antitrust Enforcement: Recent Legal Developments and Policy Implications, Address Before the American Bar Association Section of Antitrust Law Fall Forum 17 (Nov. 18, 2003), available at http://www.usdoj.gov/atr/public/ speeches/201509.pdf .

6. See Podgor, supra note 2, at 30 (suggesting a "defensive territoriality" approach to avoid the "frightening" "ramifications of continuing to use a jurisdictional base that operates aggressively"); cf. Wurmnest, supra note 3, at 210 (noting that the effects test has caused friction with foreign sovereigns).

The attention to the issues has not been confined to the courthouse. One Department of Justice official, addressing "U.S. 'judicial imperialism' in private antitrust damages actions," noted the "level of attention and concern the [extraterritoriality] cases have attracted in the international community." Delrahim, supra note 5, at 8-9.

Beyond merely posing difficult substantive issues, the Empagran litigation raised a hubbub of tremendous proportions in the international commercial and regulatory communities. See, e.g., Hannah L. Buxbaum, National Courts, Global Cartels: F. Hoffman-LaRoche Ltd. v. Empagran S.A., 5 German L.J. 1095, 1096 (2004) ("foreign receptivity to U.S. enforcement efforts came to an end" as a result of the lower court's opinion in Empagran). The line-up of amici curiae in the Supreme Court included, on the petitioner's side, several national governments and business organizations. See the Supreme Court online docket for 03-724, http://www.supremecourtus.gov/docket/ 03-724.htm (last visited Feb. 7, 2006). Amici included the governments of the United States, Canada, Germany, Belgium, the United Kingdom, Northern Ireland, the Netherlands and Japan, and business organizations such as the U.S. Chamber of Commerce, the Organization for International Investment, the International Chamber of Commerce, and an association of European banks. See id. On the respondent's side, a public-interest firm and myriad economics and law professors filed papers as amici. See id. Amici for respondent included the public interest firm Public Citizen, a so-called Committee to Support the Antitrust Laws, and several notable economists and economics professors and law professors. See id.

None of this excitement should be a surprise when one considers the size of the potential damages awards at issue in litigation that, like Empagran, raises the possibility of applying to claims by world-wide plaintiff classes the U.S. approach of trebling damages awards in antitrust litigation. See Clayton Act $\$ 4,15$ U.S.C. $\$ 15$ (2000). Treble damage awards are by no means a universally, or even commonly, accepted remedy. See Griffin, supra note 3, at 516. So too with procedural aspects of antitrust litigation in the United States, perhaps most notably the class action device. See id.; see also supra note 5 and accompanying text. 
Congress sought to forestall those issues in 1982 with the Foreign Trade Antitrust Improvements Act (FTAIA). ${ }^{7}$ When lower courts demonstrated a failure to understand the statute, the Supreme Court took up this problem in the most recent in a long line of decisions testing the extraterritorial reach of the U.S. antitrust laws - a line extending back nearly a century to Justice Holmes's 1909 opinion in American Banana Co. v. United Fruit Co. ${ }^{8}$ In the Supreme Court's only direct foray into the text of the FTAIA, F. Hoffman-LaRoche Ltd. v. Empagran S.A., ${ }^{9}$ the Court held that the statute precluded U.S. courts' hearing claims by foreign plaintiffs alleging harm felt in wholly foreign commerce. ${ }^{10} \mathrm{Em}$ pagran's narrow holding applied to claims of foreign harm with no nexus to an effect in domestic U.S. commerce. ${ }^{11}$

The Empagran Court included in its opinion an important exception. While plaintiffs not alleging a sufficient nexus between an effect in domestic commerce and their own wholly foreign harm are precluded from suit in federal court, plaintiffs able sufficiently to show that "the anticompetitive conduct's domestic effects were linked to [their] foreign harm" are excepted from the limitation. ${ }^{12}$ This is the "Empagran exception."

Ongoing litigation in lower courts shows the Empagran exception encourages artful pleading of nexuses between domestic effects and foreign harm, injecting as much uncertainty into the extraterritoriality analysis and into the understanding of the FTAIA as existed before Empagran. ${ }^{13}$ On remand (Empagran II), ${ }^{14}$ the lower court held that the plaintiffs' allegations-that fixed prices in domestic U.S. commerce were the but-for cause of their harm as purchasers in wholly foreign commerce-fell short of the nexus requirement. ${ }^{15}$ Some courts have followed suit, and some have diverged. ${ }^{16}$ As these inconsistent decisions show, the battle over extraterritoriality now has shifted to how to define the degree of nexus required under the Empagran exception. ${ }^{17}$ This issue will not resolve it-

7. See 15 U.S.C. $\$ 6(\mathrm{a})$.

8. 203 U.S. 347 (1909). See generally Max Huffman, A Retrospective on 25 Years of the Foreign Trade Antitrust Improvements Act, 70 Hous. L. REv. (forthcoming 2007).

9. 542 U.S. 155 (2004).

10. Id. at 159 .

11. Id.

12. Id. at 175; see S. Lynn Diamond, Empagran, the FTAIA and Extraterritorial Effects: Guidance to Courts Facing Questions of Antitrust Jurisdiction Still Lacking, 31 Brook. J. INT'L L. 805, 806 (2006).

13. See infra notes 194-227 and accompanying text (describing cases); Diamond, supra note 12, at 829 (arguing the Empagran decision has paved the way for another circuit split on the meaning of the Empagran exception).

14. Empagran, S.A. v. F. Hoffmann-LaRoche Ltd., 417 F.3d 1267 (D.C. Cir. 2005), cert. denied, 126 S. Ct. 1043 (2006) [hereinafter Empagran II].

15. Id. at 1271.

16. See Diamond, supra note 12, at 810; see also infra notes 215-234 and accompanying text (discussion of the cases).

17. See, e.g., Empagran II, 417 F.3d at 1270-71 (holding that the Empagran exception requires allegations that harm suffered in foreign commerce was proximately caused by an effect felt in domestic U.S. commerce). See also Diamond, supra note 12, at 808 (noting the confusion over the degree of nexus between foreign injury and domestic effects required by Empagran). 
self neatly. With the steadily increasing interdependence of the world economy, ${ }^{18}$ private efforts to apply U.S. laws extraterritorially will continue to be a hotbed of litigation activity. ${ }^{19}$

This Article explores the Empagran exception and proposes a comprehensive approach for its application. The Article proceeds in three parts. Part II gives a background of the statutory scheme and the prudential antitrust standing doctrine. Part III argues that the FTAIA, as interpreted by the Empagran Court, is best understood by reference to principles of antitrust standing, although the Court declined expressly to invoke the doctrine. Part IV examines courts' recent efforts to apply the Empagran exception and shows how standing doctrine will improve on those efforts.

This Article concludes that courts' efforts to apply the Empagran exception demonstrate failure to understand the essential legal scheme. Well-understood principles of antitrust standing, a prudential doctrine that permits courts to deny plaintiffs the right to sue if they are not appropriately efficient vindicators of the policies underlying the U.S. antitrust laws, together with other prudential considerations recognized by the Empagran Court, offer optimal means of dealing with issues of extraterritorial application going forward.

\section{BACKGROUND OF STANDING AND EXTRATERRITORIALITY}

\section{A. Understanding Antitrust Standing}

Standing is a threshold inquiry a court should address before turning to the merits of a plaintiff's claim. ${ }^{20}$ Standing doctrine exists to ensure the

18. See, e.g., Goeffrey C. Hazard et al., Introduction to the Principles and Rules of Transnational Civil Procedure, 33 N.Y.U. J. INT'L L. \& PoL'y 769, 769 (2001); Levenstein \& Suslow, supra note 3, at 805 (discussing forty-two multinational cartels in the 1990s); John M. Connor, Extraterritoriality of the Sherman Act and Deterrence of Private International Cartels, Purdue Univ. Dep't of Agric. Econ. Staff Paper 04-08, at 1 (2004) ("Today, many industries are led by a few multinational companies with sales spread across the Northern Hemisphere ....").

19. See Delrahim, supra note 5, at 17; 2 Spencer Weber Waller, Antitrust AND American Business Abroad § 13:23 (3d ed. 1997)

(This issue is being tested in the current wave of cases testing whether foreign purchasers injured abroad may sue in the United States when there is a substantial domestic impact, but where the plaintiff's injury is felt solely outside the United States .... Despite the Supreme Court's decision in Empagran, important questions remain as what circumstances, if any, foreign antitrust plaintiffs suffering injury abroad can bring their claims to U.S. courts. Years of additional litigation or statutory change will be necessary to definitively resolve this critical question.)

(footnotes omitted). See also id. § 9:7 ("The FTAIA is an immensely important statute."). Cf. John H. Robinson, The Extraterritorial Application of American Law: Preliminary Reflections, 27 J.C. \& U.L. 187, 203 (2000) (predicting a "flood of private international litigation").

20. See 1 Phillip E. Areeda \& Herbert Hovenkamp, Fundamentals of AntiTRUST LAW $\S 3.03(\mathrm{~d})$, at 97 (2003) (noting that "the antitrust injury doctrine depends less on the plaintiff's proof than on its theory of injury, and theories that do not depend on proof are well suited to pre-discovery disposition”); id. § 3.03(a), at 91 (antitrust injury 
plaintiff suing is appropriately situated to vindicate the purposes of the antitrust laws. ${ }^{21}$ The purpose of the private action, in turn, is twofold: (1) deterring conduct Congress has determined to be inimical to U.S. economic interests, and (2) compensating plaintiffs for harm suffered by an antitrust violation. ${ }^{22}$

Antitrust standing doctrine enjoys a long pedigree. The common-law background to the Clayton Act section 4 ("Clayton 4"), ${ }^{23}$ the private right of action provision of the antitrust scheme, was rife with extra-statutory limitations on recovery. ${ }^{24}$ Primary limitations included such wellknown concepts as proximate cause and certainty of damages. ${ }^{25}$ Early judicial glosses on the Sherman Act section 7, the precursor to Clayton 4, imposed those common-law limitations to suits by antitrust plaintiffs. ${ }^{26}$ Reliance on common-law principles was carried forward with the enactment of Clayton 4 and remains the norm today. ${ }^{27}$

There are three faces to the modern antitrust standing analysis. The first is the question of antitrust injury, a doctrine most prominently attrib-

doctrine "enables antitrust courts to dispose of more claims at an early stage of litigation by simply examining the logic of the plaintiff's theory of injury") (citing Juster Assocs. v. City of Rutland, 901 F.2d 266, 270 (2d Cir. 1990)).

"The essential attribute of the standing determination has always been that it was a question whether to decide . ..." Kenneth E. Scott, Standing in the Supreme Court-A Functional Analysis, 86 Harv. L. Rev. 645, 669 (1973).

21. This understanding of the doctrine grounds it squarely in the broader classical prudential standing framework. See Scott, supra note 20, at 647 (quoting HenRY M. HART \& Herbert Wechsler, The Federal Courts and the Federal System 174 (1953)) (standing ensures the plaintiff has "a sufficient personal interest" or is a "sufficiently appropriate representative" of other interested plaintiffs).

22. See Phillip Areeda, Antitrust Violations Without Damage Recoveries, 89 HARv. L. Rev. 1127, 1127 (1976); William H. Page, The Scope of Liability for Antitrust Violations, 37 Stan. L. Rev. 1445, 1450-51 (1985) (citing Daniel Berger \& Roger Bernstein, An Analytical Framework for Antitrust Standing, 86 YALE L.J. 809 (1977)).

23. 15 U.S.C. $\$ 15(\mathrm{a})$ (2000). The section reads in pertinent part:

(a) Amount of recovery; prejudgment interest

[A]ny person who shall be injured in his business or property by reason of anything forbidden in the antitrust laws may sue therefore ....

24. See Associated Gen. Contractors of Cal. v. Cal. State Council of Carpenters, 459 U.S. 519, 532-33 (1983).

25. See id. at 532 (citing Francis H. Bohlen, Cases on the Law of Torts 292-312 (2d ed. 1925), and 3 John D. Lawson, Rights, Remedies, and Practice 1740 (1890)). As Judge Posner colorfully has noted, these limitations include the following:

[V]enerable principles of tort causation illustrated by Gorris v. Scott, 9 L.R. Ex.-125 (1874). The plaintiff's animals, which were being transported on the deck of the defendant's ship, were washed overboard in a storm. They would have been saved if the deck had been penned, as required by statute. But since the purpose of the statute was to prevent contagion, not drowning, the defendant was not liable.

Jack Walters \& Sons Corp. v. Morton Bldg., Inc., 737 F.2d 698, 708-09 (7th Cir. 1984).

26. See, e.g., Loeb v. Eastman Kodak Co., 183 F. 704, 709 (3d Cir. 1910) (no standing for shareholder of victim company because the injury was "indirect, remote and consequential").

27. See Associated Gen. Contractors, 459 U.S. at 531 ("Congress intended the [Sherman] Act to be construed in the light of its common-law background."); $c f$. Am. Soc'y of Mech. Eng'rs, Inc. v. Hydrolevel Corp., 456 U.S. 556, 568 n.6 (1982) ("imposing liability .. . in accord with those common-law [agency] principles honors the congressional intent behind the antitrust statutes"). 
uted to Brunswick Corp. v. Pueblo Bowl-O-Mat, ${ }^{28}$ which requires the injury over which a plaintiff sues to be an injury of the sort the antitrust laws were intended to prevent. ${ }^{29}$ The second is the "indirect purchaser" analysis from Illinois Brick Co. v. Illinois. ${ }^{30}$ As among plaintiffs who seek standing as customers, only those that purchased directly from the defendant have standing to sue for antitrust injury. ${ }^{31}$ The third face of the standing inquiry is a vaguely defined amalgam of considerations contributing to the prudential question whether a court should entertain a private antitrust action. ${ }^{32}$

\section{The Classical Standing Framework}

The Supreme Court's most complete and coherent statement of the antitrust standing doctrine came in Associated General Contractors of California v. California State Council of Carpenters. ${ }^{33}$ The Court announced an inquiry involving five considerations courts should balance to determine whether the plaintiff is appropriately situated to vindicate the policies of the antitrust laws. ${ }^{34}$ Those considerations included the following: (1) the question of antitrust injury; (2) whether the plaintiff is a direct purchaser; (3) whether other plaintiffs are available to sue if standing is denied to this plaintiff; (4) concerns for "judicial manageability"; and (5) concerns for "either the risk of duplicate recoveries ... or the danger of complex apportionment of damages." 35

28. 429 U.S. 477 (1977).

29. Harm is a requirement of the prudential antitrust standing doctrine, which turns in part on whether a plaintiff's "harm" can be termed "antitrust injury." See Associated Gen. Contractors, 459 U.S. at 535; Brunswick, 459 U.S. at 489. See also Areeda, supra note 22, at 1130; John E. Lopatka \& William H. Page, Brunswick at 25: Antitrust Injury and the Evolution of Antitrust Law, 17 AnTITRUst 20, 20-21 (2002). Harm is also a requirement of Article III standing. As a constitutional matter, federal courts only have the power to hear a case if there is "injury in fact." See Associated Gen. Contractors, 459 U.S. at 535 n.31 (differentiating between Article III standing and antitrust standing). "Antitrust injury" is injury that flows from a violation of the antitrust laws, and not just from a violation, but from that which made the conduct illegal. See Brunswick, 429 U.S. at 486-87 (rejecting the argument that plaintiffs need only prove "they are in a worse position than they would have been had petitioner not committed those acts," and requiring proof of "antitrust injury, which is to say injury of the type the antitrust laws were intended to prevent and that flows from that which makes defendants' acts unlawful").

30. 431 U.S. 720 (1977).

31. Id. at 729 .

32. The plaintiff must be an appropriately efficient plaintiff to vindicate the purposes of the antitrust laws. In addition to antitrust injury, to have antitrust standing the plaintiff must convince the court that factors such as the directness of the injury, the existence of other plaintiffs, concerns for manageability of the litigation, and the danger of complex damages apportionment weigh in favor of the plaintiff's suit proceeding. See Associated Gen. Contractors, 459 U.S. at 540-44.

33. Id. at 519. See generally deAtucha v. Commodity Exchange, Inc., 608 F. Supp. 510, 513 (S.D.N.Y. 1985) (noting that "analysis of standing under [Clayton Act] $\$ 4$ " should start "with the Supreme Court opinions [in Associated General Contractors and Blue Shield of Virginia v. McReady, 457 U.S. 465 (1982)]").

34. Associated Gen. Contractors, 459 U.S. at 540-44.

35. Id.

Courts and commentators differ on the precise formulation of the Associated General Contractors factors. For example, one commentator has read into Associated General Con- 
Antitrust injury requires that the plaintiff "must prove ... injury of the type the antitrust laws were intended to prevent and that flows from that which makes the defendants' acts unlawful." ${ }^{36}$ Brunswick held a plaintiff could not sue for injury caused by an increase in competition from the defendant's acquisition of the plaintiff's competitor. ${ }^{37}$ Other contexts of the application of the injury doctrine include preventing claims by employees alleging harm from conduct that harms their employers and claims by plaintiffs with a business relationship with the victim of an antitrust violation. ${ }^{38}$ The injury doctrine "is typically interpreted as a requirement that the plaintiff's injury result from increased prices or decreased output." 39

Illinois Brick precludes plaintiffs from suing as purchasers alleging harm on a pass-through theory, whereby the harm suffered from paying inflated prices to a middleman is derivative of the middleman's own harm. ${ }^{40}$ The primary concern underlying the Illinois Brick holding is the

tractors a sixth element in the standing analysis, that of the defendant's intent toward the particular plaintiff. See C. Douglas Floyd, Antitrust Victims Without Antitrust Remedies: The Narrowing of Standing in Private Antitrust Actions, 82 Minn. L. REv. 1, 8 (1997) (citing Associated Gen. Contractors, 459 U.S. at 537). See also Associated Gen. Contractors, 459 U.S. at 537 n.35 ("specific intent of defendant to cause injury to a particular class of persons should 'ordinarily be dispositive' in creating standing to sue") (citation omitted); Reazin v. Blue Cross \& Blue Shield of Kan., Inc., 899 F.2d 951, 963 (10th Cir. 1990) (highlighting evidence that the defendant "specifically intended to harm" the plaintiff). The opaque discussion in Associated General Contractors of this element concludes that "improper motive . . . is not a panacea that will enable any complaint to withstand a motion to dismiss." Associated Gen. Contractors, 459 U.S. at 537. "[T]he motive allegation [is not] of controlling importance." Id. at 537 n.37.

36. Brunswick Corp. v. Pueblo Bowl-O-Mat, 429 U.S. 477, 489 (1977).

The injury requirement is analogous to the "directness" requirement of the broader prudential standing framework. See Scott, supra note 20, at 652. And while the current statement of the antitrust injury rationale is less than thirty years old, the doctrine has a long pedigree. As early as 1910, the Third Circuit held that "neither a creditor nor a stockholder . . . that was injured by a violation of the antitrust laws could recover treble damages." Associated Gen. Contractors, 459 U.S. at 533 (citing Loeb v. Eastman Kodak Co., 183 F. 704, 709 (3d Cir. 1910)).

37. Brunswick, 429 U.S. at 489-90. The plaintiff alleged the competitor otherwise would have gone out of business, giving plaintiff a monopoly. Id. at 488; Roger D. Blair \& William H. Page, The Role of Economics in Defining Antitrust Injury and Standing, in Economic Imports, Legal Outputs: The Role of Economics in Modern Antitrust 69, 70 (Fred S. McChensey ed., 1998). The Court noted that "if respondents were injured ...., while respondents' loss occurred 'by reason of' the unlawful acquisitions, it did not occur 'by reason of' that which made the acquisitions unlawful." Brunswick, 429 U.S. at 488. "What made the merger unlawful, however, was the potential for predatory behavior on Brunswick's part. But this had nothing to do with Pueblo's reduced profits." Blair \& Page, supra, at 70.

38. Hairston v. Pac. 10 Conference, 101 F.3d 1315, 1320-21 (9th Cir. 1996) (Trott, J., concurring) (no antitrust standing for business associates of victim of an antitrust violation); Ostrofe v. H.S. Crocker Co., 740 F.2d 739, 751 (9th Cir. 1984) (Kennedy, J., dissenting) (dissenting from a finding of employee standing). Those types of cases have in common the fact that the plaintiff's harm is derivative of the harm suffered by another.

39. Paul J. Stancil, Atomism and the Private Merger Challenge, 78 Temp. L. Rev. 949, $972(2005)$.

40. In Illinois Brick Co. v. Illinois, the plaintiffs alleged harm from a price-fixing conspiracy. 431 U.S. 720, 726-27 (1977). The plaintiffs did not purchase directly from the defendants, but were end users of the products. Id. at 727 . They alleged harm on a "passthrough" theory. Id. The direct purchasers were distributors, who sold to contractors, 
resulting duplicate recovery if both direct and indirect plaintiffs are able to sue. ${ }^{41}$ Another concern is preventing undue complexity of damages calculations. ${ }^{42}$ Illinois Brick serves the same essential function as the antitrust injury element in the case of plaintiffs who are purchasers, rather than competitors. ${ }^{43}$

The other three elements of the Associated General Contractors standing inquiry speak generally to the question whether the plaintiff is an efficient vindicator of the purposes of the antitrust laws. A failure to establish one or all of the remaining elements should not destroy standing for a plaintiff that can establish antitrust injury or, if relevant, direct purchase. But meeting the latter three elements might perhaps create standing where the first two elements are not met. ${ }^{44}$ For example, in Blue Shield of Virginia v. McCready, a patient was held to have standing to sue her health insurance provider, alleging a conspiracy to exclude psychologists from Blue Shield's health plans. ${ }^{45}$ The McCready plaintiff failed both the injury and indirect purchaser tests but was permitted to sue nonetheless. ${ }^{46}$

Standing more likely will be found for the particular plaintiff before the

who in turn sold to plaintiffs. $I d$. at 726 . They claimed to pay higher prices for the products because the direct purchasers' prices were passed to their customers, who in turn passed them on to the plaintiffs. Id. at 724 .

41. Id. at 730-31 (citing Hawaii v. Standard Oil Co. of Cal., 405 U.S. 251 (1972)).

42. Id. at 731-32. Professor Hovenkamp argues that Illinois Brick overstates the difficulty of calculating damages to indirect purchasers because the calculation need not involve the impossible calculation of passed-on damages. See Hovenkamp, supra note 3, at 74-75. He recommends Illinois Brick be overruled. See id. at 306-07.

43. But cf. Standard Oil, 405 U.S. at 264 (holding a state does not have standing to sue in parens patriae status for harm to its general economy based partly on a concern for duplicate recovery).

The "business associate" form of derivative harm, see Pac. 10 Conference, 101 F.3d 1315, is more closely analogous to the Illinois Brick rule than it is to the Brunswick rule. A business associate of a direct victim certainly suffers harm from that which made the defendant's conduct illegal, but the harm is derivative. So too with the harm suffered by an indirect purchaser.

Professor Hovenkamp recently has argued that the Illinois Brick rule is under-deterrent in that not all of harm suffered by an antitrust violation is remediable. See HovenkAmp, supra note 3, at 73-76. Professor Stancil is in accord. "Illinois Brick has had a substantial chilling effect on all types of private antitrust litigation. In the thousands of industries typified by multiple layers of distribution, Illinois Brick completely denies relief to the ultimate consumers of a product." Stancil, supra note 39, at 975. More, under Illinois Brick, the parties furthest removed from the violation, and thus least able to protect themselves through contract, are precluded from a remedy in antitrust. $C f$. id. (suit left to direct purchasers "who have existing commercial relationships with the wrongdoers").

44. See, e.g., Blue Shield of Virginia v. McCready, 457 U.S. 465, 485 (1982) (finding standing in a situation in which commentators agree antitrust injury was not satisfied).

45. Id. at $478-81$.

46. The much-criticized holding in Blue Shield of Virginia v. McCready is supported by the "other plaintiff" element of the standing analysis. See id. at 484-85 (Clayton $\$ 4$ applies to "any person" injured "by reason of" an antitrust violation). In McCready, there was concern that if this plaintiff did not sue, no plaintiff was available to sue.

For criticism of McCready, see, e.g., id. at 485-86 (Rehnquist, J., dissenting); Page, supra note 22, at 1449 ("The Court's attempt to fit the various doctrines into a coherent pattern, however, was notably unsuccessful. McCready is particularly unfortunate because it seriously undermines the concept of antitrust injury."). 
court if no other private persons would make appropriate plaintiffs. ${ }^{47}$ The "other plaintiff" element is explained by the perhaps self-evident proposition that for the deterrent function of the private remedy to be fulfilled, some private plaintiff should be able to sue to vindicate harm caused by an antitrust violation. If no other private plaintiff exists, and the other elements of the Associated General Contractors analysis are satisfied, it would frustrate the purposes of the private remedy to deny standing to this plaintiff. ${ }^{48}$

The "other plaintiff" element is difficult to justify under the compensation rationale for the private antitrust action. A plaintiff that has suffered antitrust injury should be entitled to an opportunity to prove its right to compensation, whether or not other plaintiffs also enjoy a right to seek compensation. ${ }^{49}$ For this reason, the "other plaintiff" element should not be permitted to destroy standing that exists under antitrust injury and direct purchase. The compensation function will be served only if every plaintiff suffering antitrust injury is permitted to sue. ${ }^{50}$

Standing is less likely to be found if a suit by that plaintiff would be unmanageable for the court system. ${ }^{51}$ The Court in Associated General Contractors gave scant indication how to understand this element of the analysis. $^{52}$ Antitrust injury and direct purchase are specific instances of

47. Associated Gen. Contractors of Cal. v. Cal. State Council of Carpenters, 459 U.S. 519, 542 (1983).

48. Professor Hovenkamp notes, "[o]f course, the remote plaintiff may become the only one when the immediate victim has some reason to avoid suing or is itself deficient in standing, antitrust injury, or ability to prove damages." ArEedA \& Hovenkamp, supra note $20, \S 3.05 \mathrm{e}$, at $112-13$.

49. Cf. Anza v. Ideal Steel Supply Corp., 126 S. Ct. 1991, 1999-2000 (2006) (Thomas, J., concurring in part and dissenting in part) ("the Court's approach also eliminates recovery for plaintiffs whose injuries are precisely those that Congress aimed to remedy through the authorization of civil RICO suits"); id. at 2003 ("our recognition in Holmes [v. Securities Investor Protection Corp., 503 U.S. 258 (1992)] that limiting recovery to direct victims would not undermine deterrence does not support the conclusion that any victim whose lawsuit is unnecessary for deterrence is an indirect victim").

50. See id. at 2003 ("If multiple plaintiffs are direct victims of a tort, it would be unjust to declare some of their lawsuits unnecessary for deterrence, absent any basis for doing so in the relevant statute.").

But see Page, supra note 22, at 1452 ("If compensation were taken as a standard, then all causally related harms would be compensable, and the resulting deterrent effects would be unpredictable from an economic point of view."). Professor Page's argument assumes the compensation function is permitted to override the antitrust injury requirement. This Article treats the injury element as an essential prerequisite to achieving the appropriate level of compensation.

51. Associated Gen. Contractors, 459 U.S. at 543 n.50 (noting that a concern for judicial manageability was discussed in the legislative history of the Sherman Act). Statements by Senator Edmunds contained in the legislative history of the Sherman Act noted concerns that "everybody might sue everybody else in one common suit and have a regular pot-pourri of the affair ... and take twenty years in order to get a result as to a single one of them." Id. at 544 n.50 (quoting 21 Cong. Rec. 3148 (1890)).

52. An analogy might be made to the context of class action certification. One requirement for certification of a class under Federal Rule of Civil Procedure 23(b)(3) is that the class be manageable. "Manageable," in the context of Rule 23, requires a court to balance the benefits to be gained from certification against the administrative and ministerial challenges inherent in entertaining the action as a class action. 7AA CHARLEs Alan Wright et al., Federal Practice \& Procedure $§ 1780$ (3d ed. 2005). Certification 
the application of the manageability element. ${ }^{53}$ The more direct a plaintiff's injury, the less danger of "long and complicated proceedings involving massive evidence and complicated theories." 54 If a plaintiff's harm is a sort meant to be protected against, the unmanageability threshold the system should be willing to endure to provide that plaintiff a remedy is much higher. ${ }^{55}$

For the compensation function of the private remedy to be served, the manageability element cannot destroy standing that exists under the first two elements. A simple cost-benefit analysis supports this conclusion. The marginal cost to the system of each additional plaintiff, especially in the context of class action litigation, is small and decreasing, and the difference between the marginal benefit to the plaintiff and the marginal cost to the defendant from permitting each individual plaintiff to sue remains constant as the number of plaintiffs increases. Thus, the same arguments for permitting one plaintiff to sue support permitting another to sue. The result is that if a plaintiff can demonstrate antitrust injury and direct purchase, no matter how unwieldy the litigation, that plaintiff should be permitted to sue. ${ }^{56}$

Courts also should consider whether permitting the plaintiff's suit would create the risk of complex apportionment of damages. ${ }^{57}$ The archetypal example of denying standing for concerns of complexity is $\mathrm{Ha}$ waii v. Standard Oil Co. ${ }^{58}$ The Court in Hawaii v. Standard Oil Co. denied standing to sue in parens patriae status to a state government seeking to collect for harm suffered generally in the state economy. ${ }^{59}$ An important underpinning of that holding was the impossibility of proving the amount of relief to be awarded. ${ }^{60}$ The Court re-emphasized the com-

should not be granted if the challenges are not overborne by corresponding efficiency benefits. Id. Analogous to Senator Edmunds' concerns in 1890, the manageability criterion aims to streamline the "interminable litigation" that might occur when large numbers, all claiming an interest in the subject matter of a suit, are permitted to sue.

53. Associated Gen. Contractors, 459 U.S. at 543.

54. Id. (quoting Hanover Shoe, Inc. v. United Shoe Mach. Corp., 392 U.S. 481, 493 (1968)).

55. Determining whether the concern for unmanageability should be permitted to override a plaintiff's right to compensation involves a calculus of the systemic costs from suit measured against the overall benefits directly attributable to the suit.

56. If the fact of unmanageability of the litigation can undo standing for private plaintiffs, an antitrust violator would be well-served to harm as many plaintiffs as possible-the opposite of the deterrence goal of the private remedy. Cf. WRIGHT ET AL., supra note 52 (noting concerns for procedural limits on class actions different from the right of the plaintiff to sue, giving defendants incentives to harm as many plaintiffs as possible, thereby undermining manageability).

57. Associated Gen. Contractors, 459 U.S. at 545.

58. 405 U.S. 251 (1972).

59. See id. at 262-66.

60. Id. at 264 n.14 ("Measurement of an injury to the general economy, on the other hand, necessarily involves an examination of the impact of a restraint of trade upon every variable that affects the State's economic health - a task extremely difficult, in the real economic world rather than an economist's hypothetical model." ") (quoting Hanover Shoe, Inc. v. United Shoe Mach. Corp., 392 U.S. 481, 489 (1968)). Standard Oil also relied on the danger of duplicate recovery, the rationale underlying Illinois Brick. Ill. Brick Co. v. Illinois, 431 U.S. 720, 730-31 (1977) (citing Standard Oil, 405 U.S. at 264). 
plexity concern in the 2006 Term in Anza v. Ideal Steel Supply Corp. ${ }^{61}$ In that case, decided under the Racketeering Influenced and Corrupt Organizations Act ("RICO"), which contains a private right of action provision modeled on Clayton 4,62 the Court noted the "complex assessment" that would be required to determine which of the plaintiff's losses were attributable to the defendant's conduct. ${ }^{63}$

\section{Protecting the Purposes of Private Enforcement}

Scholarship supports the proposition that the ideal private remedy is one that serves perfectly the deterrent function. ${ }^{64}$ The challenge facing courts is to fashion remedies that both deter and compensate appropriately-a process to which scholars have referred as "optimizing" remedies. ${ }^{65}$ Four interrelated bodies of doctrine-substantive standards for antitrust liability, ${ }^{66}$ subject-matter jurisdiction of U.S. antitrust courts, ${ }^{67}$ the scope of the treble damages remedy, ${ }^{68}$ and standing for private antitrust plaintiffs ${ }^{69}$ - operate to create, and to limit, the recovery available to a private antitrust plaintiff. ${ }^{70}$ Of those, the prudential standing analysis is the best candidate for optimizing the remedies available to private plain-

61. 126 S. Ct. 1991 (2006).

62. See id. at 1996; Holmes v. Sec. Investor Prot. Corp., 503 U.S. 258, 260 (1992); Associated Gen. Contractors, 459 U.S. 519.

63. Anza, 126 S. Ct. at 1997 ("Businesses lose and gain customers for many reasons, and it would require a complex assessment to establish what portion of Ideal's lost sales were the product of National's decreased prices."). The Court also specifically distinguished the complexity concern from the Illinois Brick concern for duplicate recoveries. Id. at $1997-98$.

64. Page, supra note 22, at 1450-52. Professor Page has argued that of the dual purposes of private antitrust enforcement, "the deterrent function must predominate" in determining the appropriate private remedy. See id. at 1451. Professor Page argues that deterrence makes compensation to private plaintiffs unnecessary. Id. at 1452. That argument creates a chicken and egg problem-compensation is necessary to incentivize private plaintiffs to bring suit to deter violations. Professor Page implicitly recognizes the role of compensation in evaluating the perfect antitrust remedy: "Any system of deterrence must define the size of the deterrent penalty and identify the person who will bring suit." Id. (emphasis added).

65. See Hovenkamp, supra note 3, at 66-67; Keith N. Hylton, Antitrust Law: Economic Theory and Common Law Evolution 43-44, 49-52 (2003); William M. Landes, Optimal Sanctions for Antitrust Violations, 50 U. CHI. L. Rev. 652, 678 (1983).

66. See 15 U.S.C. $\$ \S 1-7(2000)$.

67. Subject-matter jurisdiction generally has been the repository of the extraterritoriality analysis. See id. §6(a) (FTAIA); see generally infra notes 87-91 and accompanying text.

68. See Clayton Act $\S 4,15$ U.S.C. $\S 15(a)$.

69. See Page, supra note 22, at 1446-47 (treating antitrust standing, the Illinois Brick doctrine, and the antitrust injury doctrine from Brunswick as "three major doctrines [that] have been called into service" to "set economically rational limits on the size of treble damage liability and on the frequency of antitrust litigation"). Associated General Contractors treated those doctrines as elements of the standing analysis. See Associated Gen. Contractors of Cal., Inc. v. Cal. State Council of Carpenters, 459 U.S. 519, 545 (1983).

70. One more body of doctrine that might be thought to contribute to the goal of optimizing remedies is the body of rules for pleading an antitrust case. See generally Brief for Legal Scholars Amici Curiae Supporting Petitioners, Bell Atlantic Corp. v. Twombly, 127 S. Ct. 575 (2006) (No. 05-1126). 
tiffs in light of the purposes those remedies should serve. ${ }^{71}$ Whether and how remedies are to be administered depends largely on the prudential question which plaintiffs will be permitted to sue. ${ }^{72}$

A problem unique to private enforcement is that plaintiffs are-and should be-motivated solely by their individual best interests. ${ }^{73}$ They are thus ill-incentivized to temper their litigation with broader systemic concerns. By contrast, the federal enforcement agencies in recent decades have operated with views toward the policies of economic efficiency most courts and commentators agree should be advanced by U.S. antitrust enforcement. ${ }^{74}$

But little incentive exists for private plaintiffs to limit their claims, so the remedy does not result in too great of deterrence by the defendant. ${ }^{75}$ In private enforcement, then, courts are given the task of optimizing rem-

71. See Page, supra note 22, at 1450 (noting the "complementary relationship" of antitrust injury and standing "in approximating the standard of optimal deterrence"). Substantive standards for liability, subject-matter jurisdiction, and the scope of the treble damages remedy, which are the most firmly grounded in statute and the least malleable, are the least likely candidates for optimization. But see HovenkAmP, supra note 3, at 305-06 (recommending amendments to the antitrust laws to reduce the use of treble damages remedy).

72. See Page, supra note 22, at 1446-47 (describing "three major doctrines" that are employed to "set economically rational limits on the size of treble damage liability and on the frequency of antitrust litigation."). This Article has argued that the three doctrines are subsumed into the Associated General Contractors standing analysis.

73. See Hovenkamp, supra note 3 , at 58 (noting that private plaintiffs are not concerned with general welfare); Page, supra note 22, at 1445 ("firms quite rationally employ a rent-seeking antitrust strategy, whose aim is not only to exact treble damages, but to inhibit rivalry and efficient distribution practices"); Stancil, supra note 39, at 950 ("[p]rivate parties act in their own perceived self-interest"). Professor Hylton also argues that the private right of action provision in Clayton 4 is exceptionally broad. See Hylton, supra note 65, at 58 ("There is probably no more plaintiff-friendly statute in all of the federal laws.").

74. See United States v. Syufy Enters., Inc., 903 F.2d 659 (9th Cir. 1990); Brief of the United States at 1, Bell Atlantic Corp. v. Twombly, 127 S. Ct. 575 (2006) (No. 05-1126), available at http://www.usdoj.gov/osg/briefs/2006/3mer/1ami/2005-1126.mer.ami.pdf (noting that the Department of Justice "seeks to further 'our fundamental national economic policy' of competition" in its antitrust enforcement efforts). See generally William E. Kovacic, The Modern Evolution of U.S. Competition Policy Enforcement Norms, 71 AnTitrust L.J. 377 (2003).

As to the relevance of economic analysis to antitrust enforcement generally, see for example, Richard A. Epstein \& Michael S. Greve, Introduction: The Intractable Problem of Antitrust Jurisdiction, in COMPETITION LAws in CONFLict: ANTITRUST JURISDiction IN A Global Economy 1, 1 (Richard A. Epstein \& Michael S. Greve eds., 2004). See also generally Robert H. Bork, The Antitrust Paradox (Rev. ed. 1993); Hylton, supra note 65; Richard A. Posner, Antitrust Law (2d ed. 2002); The Political Economy of the Sherman Act: The First One Hundred Years (E. Thomas Sullivan ed., 1991); Timothy J. Muris, Principles for a Successful Competition Agency, 72 U. CHI. L. REv. 165, 168, 170 (2005); Stancil, supra note 39, at 958-59 (detailing the progression of antitrust values culminating in the "consumer welfare" standard).

75. An exception might exist for a plaintiff that might find itself a defendant in future litigation raising the same issues. Research has uncovered no analysis of the degree to which private plaintiffs consider their own potential future liability in their litigation decisions. Such an analysis would be helpful in understanding parties' litigation decisions.

Psychological factors are relevant here as well. Private plaintiffs overvalue their claim because they might be blind to factors apart from the defendant's conduct - such as mismanagement of their business - that caused or contributed to the harm they suffered. The massive incentives for private plaintiffs to engage in antitrust litigation overwhelm any realistic hopes for self selection. 
edies. ${ }^{76}$ That is a question of balancing concerns for over-deterrence and under-deterrence.

Over-deterrence is the chilling of economically useful conduct through the specter of the liability that will be imposed if that useful conduct should cause harm. ${ }^{77}$ A standard of remedying harm that risks producing "false positives"-liability where no anticompetitive conduct actually took place - is bothersome twice over. First, it unfairly imposes liability on innocent conduct. Second, it prevents possible defendants from toeing the line between stridently competitive, highly desirable activity and anticompetitive conduct.

The opposite concern is that of under-deterrence. If the total liability stemming from anticompetitive conduct, discounted by the likelihood that liability will be imposed at all, is less than the total expected benefit from the conduct, rational economic actors will engage in the conduct. ${ }^{78}$ Conversely, if the total liability appropriately discounted exceeds the total expected benefit, they will not. The under-deterrence concern arises if either (1) the regulatory regime insufficiently penalizes conduct, or (2) the judicial system somehow fails to give full effect to the regulatory scheme.

A twist on the under-deterrence concern is an "inverse deterrence" argument that came to the fore in Empagran. Under the inverse deterrence argument, excessive private enforcement produces negative externalities that harm public enforcement efforts. This harm occurs because in recent years, public anti-cartel enforcement relies heavily on the Department of Justice's leniency program to uncover criminal antitrust conspiracies. ${ }^{79}$ The leniency program permits the first cartel member to disclose the car-

76. Professor Stancil argues "it is absolutely critical that (1) the law minimize the costs associated with inefficient opportunistic behavior on the part of private plaintiffs, and (2) the private enforcement mechanism reflects the current balance of policy considerations governing public enforcement." Stancil, supra note 39, at 950.

77. See generally Hylton, supra note 65, at 43-47 (defining over-deterrence as the deterrence of "some monopolizing activity that actually increases society's wealth") (citing Landes, supra note 65, and Gary S. Becker, Crime and Punishment: An Economic Approach, 76 J. Pol. Econ. 169, 217 (1968)).

78. See, e.g., Pfizer, Inc. v. Gov't of India, 434 U.S. 308, 315 (1978). Professor Hylton defines under-deterrence as the failure to "discourage conduct that reduces society's wealth." Hylton, supra note 65, at 43 (analyzing the size of damages award necessary to ensure sufficient deterrence). Professor Landes would define the concept more narrowly such that the cost of discouraging the conduct is part of the consideration whether the welfare loss the conduct causes is tolerable. See Landes, supra note 65, at 678.

79. See Brief for the United States and Federal Trade Commission as Amici Curiae Supporting Defendants-Appellees, at 19-21, Empagran II, 417 F.3d 1267 (D.C. Cir. 2005) (D.C. Civ. No. 01-7115). See also Thomas O. Barnett, Assistant Attorney Gen., U.S. Dep't of Justice, Seven Steps to Better Cartel Enforcement, Presentation to the 11th Annual Competition Law and Policy Workshop, European Institute 1 (Jun. 2, 2006), available at http://www.usdoj.gov/atr/public/speeches/216453.pdf. (describing the amnesty program as one of seven prongs of the Department of Justice's cartel enforcement strategy); id. at 6-7 (describing the operation and importance of DOJ's amnesty program). 
tel and cooperate with prosecutors to avoid criminal prosecution. ${ }^{80}$ But it says nothing about civil liability that might follow. ${ }^{81}$ Excessive potential civil liability decreases the likelihood that avoiding criminal liability is a sufficient incentive for a member to disclose participation in a cartel. ${ }^{82}$

\section{B. AnAlysis of the FTAIA}

Congress in 1982 recognized the burgeoning antitrust extraterritoriality issues. It enacted the FTAIA to define the scope of appropriate extraterritorial application of the U.S. antitrust laws. ${ }^{83}$ Although "an immensely important statute," 84 the FTAIA received little attention for nearly two

80. See Dep't of Justice: Antitrust Div., Corporate Leniency Policy (1993), available at http://www.usdoj.gov/atr/public/guidelines/lencorp.htm [hereinafter CoRPORATE Leniency Policy].

81. See Kruman v. Christie's Int'l PLC, 129 F. Supp. 2d 620, 622 (S.D.N.Y. 2001). The trial court in Kruman noted the following:

In January 2000, word leaked that Christie's had availed itself of the amnesty program of the Antitrust Division of the United States Department of Justice and confessed that it had engaged in fixing prices of auction services with Sotheby's. As one might expect, a veritable flood of class actions was filed in response to this news, each seeking to recover damages under the United States antitrust laws on behalf of variously described classes of purchasers and sellers who bought or sold through these houses at non-internet auctions in the United States.

Id.

82. Then, and somewhat circularly, because of the prima facie effect of a criminal conviction of antitrust conduct in a private antitrust suit, the public enforcement efforts usually provide the driving force behind private suits. So, according to the inverse deterrence argument, excessive potential civil liability can decrease the effectiveness of antitrust enforcement at all levels. In effect, the inverse deterrence rationale threatens the same effect as under-deterrence-reducing the regulatory scheme's effectiveness at uncovering existing antitrust conspiracies.

Congress in 2004 passed the Antitrust Criminal Penalty Enhancement and Reform Act, Pub. L. No. 108-237, 118 Stat. 666 (2004), limiting to mere compensatory relief the damages available from a defendant that had availed itself of the amnesty program. See 15 U.S.C. § 213(a) (2000). The limitation should reduce, although not eliminate, cartel members' disincentives to turn state's evidence. Research does not uncover analyses of the statute's effectiveness.

83. Id. $\S 6(\mathrm{a})$. The FTAIA reads in full:

Sections 1 to 7 of this title shall not apply to conduct involving trade or commerce (other than import trade or import commerce) with foreign nations unless-

(1) such conduct has a direct, substantial, and reasonably foreseeable effect-

(A) on trade or commerce which is not trade or commerce with foreign nations, or on import trade or import commerce with foreign nations; or

(B) on export trade or export commerce with foreign nations, of a person engaged in such trade or commerce in the United States; and

(2) such effect gives rise to a claim under the provisions of sections 1 to 7 of this title, other than this section.

If sections 1 to 7 of this title apply to such conduct only because of the interpretation of paragraph (1)(B), then sections 1 to 7 of this title shall apply to such conduct only for injury to export business in the United States.

84. 1 Spencer Weber Waller, Antitrust \& Am. Business Abroad § 9:7 (3d ed. Supp. 2005). 
decades ${ }^{85}$ - perhaps because of its opacity, ${ }^{86}$ perhaps because it appeared merely to codify existing law, ${ }^{87}$ or perhaps because the global stage was not until recently set for the current wave of multinational litigation. ${ }^{88}$ Even the Supreme Court's highly contentious 1993 extraterritoriality decision, Hartford Fire Insurance Co. v. California, ${ }^{89}$ relegated the primary FTAIA analysis to a footnote. ${ }^{90}$ In recent years, clever arguments by plaintiffs' counsel have resuscitated the statute. ${ }^{91}$ Shortly after the turn of the century, courts began to be receptive to those arguments. ${ }^{92}$

Like other statutes that memorialize limitations on courts' power, ${ }^{93}$ the FTAIA first takes away courts' authority over all antitrust claims in wholly foreign or export commerce-then gives some back. Congress provided that the antitrust laws "shall not apply to conduct" involving wholly foreign commerce or export trade or export commerce, "unless" an exception is met. ${ }^{94}$ The exception is comprised of two primary parts. Subsection one requires that for conduct to be within the reach of the antitrust laws, it must have "a direct, substantial and reasonably foreseeable effect" on domestic commerce, import commerce, or the business of

85. See Delrahim, supra note 5, at 3 ("it lay almost unnoticed in dusty pages of the United States Code").

86. See 2 WALLER, supra note $19, \S 13.23$ (noting the "obscure and badly drafted Foreign Trade Antitrust Improvements Act"); id. § 9:7 ("At a linguistic level, this statute clarifies nothing."); Diamond, supra note 12, at 819 (the FTAIA "is widely considered to be a poorly drafted statute") (citing Turicentro, S.A. v. Am. Airlines, Inc. 303 F.3d 293, 300 (3d Cir. 2002)). Delrahim, supra note 5, at 3 (noting the underuse of the FTAIA "may have something to do with" the FTAIA's " inelegant phras[ing]"). Opacity is not a powerful indictment of an antitrust law. It might be considered a defining characteristic of the antitrust laws. See Richard A. Posner, Antitrust Law 1 (2d ed. 2001).

87. See, e.g., F. Hoffman-LaRoche, Ltd. v. Empagran S.A., 542 U.S. 155, 169 (2004) ("Congress designed the FTAIA to clarify, perhaps to limit, but not to expand in any significant way, the Sherman Act's scope as applied to foreign commerce.") (citing H.R. REP. No. 97-686 (1982), as reprinted in 1982 U.S.C.C.A.N. 2487, 2487-88); Hartford Fire Ins. Co. v. California, 509 U.S. 764, 796 n.23 (1993).

88. See generally Huffman, supra note 8 . The statute has received more attention in the past fifteen years, during which time the detection and prosecution of international cartels became much more common. See Levenstein \& Suslow, supra note 3, at 801 (noting that in the 1990s "the U.S. Department of Justice and the European Commission prosecuted over forty international cartels for illegal price fixing").

89. 509 U.S. 764.

90. See id. at 796 n.23.

91. See, e.g., Empagran S.A. v. F. Hoffman-LaRoche Ltd., 315 F.3d 338 (D.C. Cir. 2003); Kruman v. Christie's Int'l P.L.C., 284 F.3d 384 (2d Cir. 2002); Den Norske Stals Oljeselskap As v. HeercMac V.O.F., 241 F.3d 420 (5th Cir. 2001). There is irony in plaintiffs' counsel bringing this statute to the fore. It was enacted to limit U.S. antitrust courts' extraterritorial reach. See Empagran, 542 U.S. at 169; The In Porters, S.A. v. Hanes Printables, Inc., 663 F. Supp. 494, 498 (M.D.N.C. 1987) (noting that the statute was a response to complaints by American firms that the U.S. antitrust scheme made them less competitive on the world stage). See generally Huffman, supra note 8.

92. See Empagran, 315 F.3d 338; Kruman, 284 F.3d 384.

93. Ready examples include the Federal Tort Claims Act, 28 U.S.C. $\$ \S 2671-2680$ (2005) and the Foreign Sovereign Immunities Act, 28 U.S.C. $\$ \$ 1602-1611$ (2005). See MacArthur Area Citizens Ass'n v. Republic of Peru, 809 F.2d 918, 919-20 (D.C. Cir. 1987) (comparing the FTCA with the FSIA).

94. 15 U.S.C. $§ 6(a)(1)$ (quoted in full supra note 83); see ALSO Empagran, 542 U.S. at 162 . 
U.S. exporters. ${ }^{95}$ Subsection two requires further that the conduct "give rise to a claim" under the substantive antitrust laws. ${ }^{96}$

\section{ANTITRUST STANDING IN EXTRATERRITORIAL APPLICATION}

The Empagran litigation is the source of the modern rules governing extraterritoriality. The Empagran plaintiffs sued vitamin manufacturers alleging price fixing - a violation of Sherman Act section 1 that regularly gives rise to civil and criminal penalties ${ }^{97}$ - on a worldwide scale. ${ }^{98}$ The plaintiffs, distributors of vitamins from around the globe, originally were a class of "foreign and domestic purchasers of vitamins." 99

The defendants' arguments for dismissing the foreign purchasers' claims proceeded on two fronts. First, the defendants contended the FTAIA limited the court's jurisdiction to claims of domestic harm felt as a result of the effect of antitrust-violative conduct on domestic U.S. commerce. ${ }^{100}$ Second, defendants contended the foreign purchasers lacked standing to sue. ${ }^{101}$ Under the antitrust standing approach, unless the plaintiffs suffered injuries flowing from that which makes the defendant's acts unlawful-which, defendants' argued, were the effects of the alleged conduct on U.S. commerce-the plaintiff's injuries should not be cognizable in federal court applying U.S. antitrust laws. ${ }^{102}$ In an argument foreshadowing the Supreme Court's ultimate analysis, the United States as amicus curiae noted that "principles of antitrust injury and standing" are "embedded in the FTAIA."103

95. 15 U.S.C. $§ 6(a)(1)$.

96. Id. $\S 6 \mathrm{a}(2)$ (referring to "sections 1 to 7 of this title, other than this section")

97. 15 U.S.C. $\$ 1$. "Cartels are 'the supreme evil of antitrust.' The fixing of prices, bids, output, and markets by cartels has no plausible efficiency justification; therefore, antitrust authorities properly regard cartel behavior as per se illegal or a 'hard core' violation of the competition laws." Barnett, supra note 79, at 1; Thomas O. Barnett, Assistant Attorney Gen., U.S. Dep't of Justice, Antitrust Enforcement Priorities: A Year in Review, Fall Forum of the Section of Antitrust Law 1 (Nov. 19, 2004), available at http://www.usdoj .gov/atr/public/speeches/206455.pdf (noting that "the highest enforcement priority is rooting out and prosecuting illegal cartels-naked agreements not to compete").

98. Empagran, S.A. v. F. Hoffman-LaRoche, Ltd., 315 F.3d 338, 340 (D.C. Cir. 2003).

99. Id. at 342 .

100. See Empagran S.A. v. F. Hoffman-La Roche, Ltd., No. Civ. 001686TFH, 2001 WL 761360, at *2 (D.D.C. Jan. 7, 2001); Empagran, 315 F.3d at 343.

101. See Empagran, 2001 WL 761360, at *5; Empagran, 315 F.3d at 341.

102. See Brief for the United States and the Federal Trade Commission as Amici Curiae Supporting Defendants-Appellees at 8-9, Empagran, 315 F.3d 338 (D.C. Cir. 2003) (No. 01-7115), 2005 WL 388672 [hereinafter Government D.C. Cir. Brief]. The district court dismissed the foreign plaintiffs' claims "because the conspiracy's effect on U.S. commerce did not cause the foreign purchasers' injury." Empagran, 315 F.3d at 343. It based its holding on a lack of subject matter jurisdiction and did not reach defendants' standing argument. See id.

103. Government D.C. Cir. Brief, supra note 102, at 8-9. 


\section{A. Literalist Statutory Construction and WORLDWIDE CONSPIRACY}

Plaintiffs advanced two theories why their claims were within a U.S. antitrust court's purview. The first was a reading of the FTAIA that broadened U.S. courts' extra territorial scope. This argument holds that jurisdiction may be asserted over any claim alleging harm flowing from antitrust-violative conduct, even if the conduct occurred overseas, so long as the conduct also had some effect in domestic commerce. Importantly, plaintiffs further argued the effect in domestic U.S. commerce need have no connection to their harm. ${ }^{104}$

This theory finds primary traction in a literalist interpretation of the text of the FTAIA. ${ }^{105}$ Under subsection two of the statute, for extraterritorial jurisdiction to be available, the complained-of conduct must have an appropriate effect on U.S. commerce, and "such effect" must "give[ ] rise to a claim" under the antitrust laws. ${ }^{106}$ Defendants argued the conduct alleged must give rise to the plaintiff's claim. Plaintiffs' argued the conduct alleged need only give rise to $a$ claim. It is not difficult to appreciate why the plaintiffs' proffered interpretation appeared to give proper effect to Congress's use in subsection two of the indefinite article "a," rather than the definite article "the."

In the first opinion in the recent wave of extraterritoriality cases to allow foreign plaintiffs suit to proceed, the Second Circuit in Kruman v. Christie's International PLC ${ }^{107}$ accepted a variation of the broad theory of extraterritorial jurisdiction. The Kruman court held the conduct complained of need only have violated the substantive provisions of the Sherman Act, but need not have caused any harm in U.S. commerce.108 "A claim" might include a claim brought by the United States, which is not obliged to demonstrate harm to seek injunctive relief and criminal penalties for violation of the antitrust laws. ${ }^{109}$

The D.C. Circuit opinion in Empagran was the second to adopt a liberal interpretation of the extent of extraterritorial reach permitted by the FTAIA. That court interpreted "a claim" to mean a claim by a private plaintiff, although like the Second Circuit in Kruman, it need not be

104. Empagran, 315 F.3d at 344 (inquiring whether "it [is] enough for a plaintiff to show that the anticompetitive effects of the defendant's conduct on U.S. commerce give rise to an antitrust claim under the Sherman Act by someone, even if not by the plaintiff who is before the court").

105. This sort of textual analysis recently has gained traction in antitrust decision-making. See, e.g., F. Hoffman-LaRoche, Ltd. v. Empagran S.A., 542 U.S. 155, 173-174 (2004); Transcript of Oral Argument at 10-14, Volvo Trucks N. Am., Inc. v. Reeder-Simco GMC, Inc., 126 S. Ct. 860 (2005) (No. 04-905), 2005 WL 3036314.

106. 15 U.S.C.A. $\$ 6(a)(2)$ (West 2005$)$

107. Kruman v. Christie's Int'l PLC, 284 F.3d 384 (2d Cir. 2002). The petition for certiorari in Kruman was dismissed when the case settled.

108. See id. at 399-400; Empagran, 315 F.3d at 348 (discussing the Second Circuit's holding in Kruman).

109. See 15 U.S.C. $\$ 4$ (right of action provision for the United States); Empagran, 542 U.S. at 170-71 (noting the distinction between private plaintiffs and government plaintiffs is that government plaintiffs need not show standing). 
plaintiff before the court. Thus, some plaintiff must have suffered harm in domestic U.S. commerce from the effect of the conduct. ${ }^{110}$ The foreign plaintiffs' claims would then be derivative of that domestic plaintiff's claim.

The Empagran plaintiffs' second theory became the Empagran exception. Under that theory, if the FTAIA permitted jurisdiction only over claims caused by an effect on domestic U.S. commerce, plaintiffs' claims might nonetheless be cognizable. Plaintiffs argued the defendants had been engaged in a worldwide price-fixing conspiracy, in which all conduct was interdependent on all other conduct. ${ }^{111}$ The court of appeals described the interdependence theory as one of a possibility of arbitrage by third parties purchasing at competitive prices in one location and selling below the fixed-price level in another or by would-be purchasers in pricefixed markets purchasing instead in competitive markets and importing to their home markets. ${ }^{112}$

The interdependence theory is not new. In de Atucha v. Commodity Exchange, Inc., 113 the plaintiff alleged that "because of the fungibility of silver and silver futures, the United States market . . . and the London Exchange function from an economic standpoint as a single market."114 "DeAtucha's theory of standing, as we understand it, is that he may sue under American antitrust laws because the defendants' manipulation of the American silver markets produced his injury on the [London Exchange]." 115

Economic theory supports an allegation that, in a worldwide conspiracy, stable prices in a particular geographic locale are essential to maintaining stable prices in others. ${ }^{116}$ Successful cartels only can exist in environments that permit the members to detect "cheating"-that is, pricing below the agreed cartel price in an effort to gain market share. ${ }^{117}$ Cheating in a worldwide cartel could occur if one producer arranged to

110. See Empagran, 315 F.3d at 350.

111. "Respondents contend that, because vitamins are fungible and readily transportable, without an adverse domestic effect (in other words, higher prices in the United States), the sellers could not have maintained their international price-fixing arrangement, and respondents would not have suffered their foreign injury." Empagran, 542 U.S. at 175. See Diamond, supra note 12, at 809 ("With rampant globalization, instantaneous communication, and multinationals building products with components from all over the world and selling them far from where they are produced, it may be argued that there no longer are independent, national markets.").

112. Empagran II, 417 F.3d 1267, 1270-71 (D.C. Cir. 2005).

113. 608 F. Supp. 510 (S.D.N.Y. 1985).

114. Id. at 511-12 (quoting plaintiff's complaint, II 28).

115. Id. at 513 .

116. See Connor, supra note 18, at 6 (noting the likelihood of geographic arbitrage in the world market for vitamins at issue in Empagran).

117. See Bork, supra note 74, at 102-04 (describing the incentives that make cheating on cartels likely); Katherine M. McElroy \& John J. Siegfried, The Economics of Price Fixing, in Economic Analysis and Antitrust Law 139, 143 (Terry Calvani \& John Siegfried eds., 2d ed. 1988) (conditions required to stabilize cartels); Levenstein \& Suslow, supra note 3, at 819 n.19 (collecting authorities); George J. Stigler, A Theory of Oligopoly, 72 J. Pol. ECON. 44 (1964). 
sell to distributors in a non-price-fixed market, enabling those distributors to move the product to their home markets on their own initiative, hiding the maverick producer's low-price sales from its co-conspirators. Fixing prices in every market in which the cartel members operate is a sure way to avoid this form of cheating.

The related arbitrage concern, which the D.C. Circuit noted in Empagran, is that even independent of cheating by participants in the cartel, distributors or third parties could take advantage of lower prices in one geographic market to move product on their own from a lower-priced, competitive market to a fixed-price one. ${ }^{118}$

On the other hand, strong reason exists to believe maintaining a worldwide conspiracy is sufficiently difficult that localized price-fixing behavior is much more likely. The larger the scope of the conspiracy, the more difficult and expensive should be reaching agreement among cartel members as to prices and market shares in the diverse geographic locales within the scope of the conspiracy and monitoring the behavior of coconspirators. ${ }^{119}$ Additionally, a worldwide conspiracy might involve too many players with too diverse of interests and corporate cultures to be maintainable at all. ${ }^{120}$ Those factors seem at least as likely to undermine any arguments of global interdependence in a worldwide cartel as the cheating and arbitrage arguments are to bolster them. ${ }^{121}$

On the initial appeal from the trial court, the D.C. Circuit did not address plaintiffs' theory of worldwide independence. ${ }^{122}$ Neither did the Second Circuit in Kruman inquire into the existence of a causal connection. ${ }^{123}$ By contrast, the Fifth Circuit, in Den Norske Stats Oljeselskap As v. HeereMac Vof ("Statoil"), ${ }^{124}$ did address the causal connection be-

118. A thorough analysis of this effect is found in Connor, supra note 18 .

119. See McElroy \& Siegfried, supra note 117, at 146-47 (discussing the difficulties of fine-tuning fixed prices among participants in a cartel).

120. See id. at 148 (necessity for a sufficiently small number of firms to permit control of cheating on a price agreement). One criticism of the foregoing assertions is that geographic breadth of a cartel is less important than sheer size as far as goes the challenges of maintaining solidarity among its members. Research has not uncovered analysis of which factor-size of cartel/numerosity of participants or geographic breadth-is more important. But surely they are not independent qualities. A cartel of great geographic scope is likely to be larger than one that is purely local. Also, geographic scope does present particularized challenges. Those would include some of the same language and culture barriers that accompany all cross-border business dealings.

121. But see Levenstein \& Suslow, supra note 3, at 819 (arguing that multinational cartels have features, including the presence of many markets in which punishment of deviations can occur, that may make them more cohesive); id. at 806 (discussing a set of international cartels with a mean duration of just over five years and a median duration of approximately four years, of which the longest-surviving example, a shipping cartel in Central-West Africa, lasted twenty years); Connor, supra note 18, at 7-10 (arguing the vitamins cartel at issue in Empagran was vast and sophisticated);

122. Empagran, S.A. v. F. Hoffman-LaRoche, Ltd., 315 F.3d 338, 341 (D.C. Cir. 2003).

123. Kruman v. Christie's Int'l PLC, 284 F.3d 384, 399-400 (2d Cir. 2002) (FTAIA relates to conduct, not to the injury; injury is governed by Clayton $\S 4$ ).

124. 241 F.3d 420 (5th Cir. 2001). 
tween domestic effect and foreign injury. ${ }^{125}$ In Statoil, the plaintiff had argued that "the market . . . is a single, unified, global market." 126 But "the FTAIA requires more than a 'close relationship' between the domestic injury and the plaintiff's claim; it demands that the domestic effect 'gives rise' to the claim." 127 Because the plaintiffs apparently failed to plead any causal connection, the court did not have occasion to define what degree of nexus would be required for a harm felt in domestic U.S. commerce to confer authority on a U.S. antitrust court to decide a suit over a derivative foreign harm.

\section{B. Rejecting Literalism in Favor of Prescriptive Comity}

The FTAIA precludes the assertion of jurisdiction by U.S. courts to remedy wholly foreign harm with no nexus to an effect in U.S. commerce. ${ }^{128}$ Statutory subsection one makes clear the complained-of conduct must have had a direct, substantial and reasonably foreseeable effect on domestic commerce, import commerce, or on the business of U.S. exporters. ${ }^{129}$ Statutory subsection (2) makes clear the conduct's effect on domestic U.S. commerce must have given rise to the plaintiff's claims under the antitrust laws. ${ }^{130}$ But holding there is an exception for claims of foreign harm with a sufficient nexus to the effect on U.S. commerce, the Empagran Court reversed the lower court on plaintiffs' literalist theory. ${ }^{131}$ Plaintiffs must do more than merely allege the defendant's antitrust-violative conduct gave rise to "a" claim under the antitrust laws.

125. Id. at 425 (noting argument that "Statoil's injury in the North Sea was a 'necessary prerequisite to' and was 'the quid pro quo for' the injury suffered in the United States domestic market").

126. Id. at 425 .

127. Id. at 427.

128. F. Hoffman-LaRoche, Ltd. v. Empagran, S.A., 542 U.S. 155, 159 (2004). Empagran came to the Supreme Court by way of a split among the Courts of Appeals. The Fifth Circuit in Statoil held that U.S. antitrust courts' jurisdiction did not extend to harm suffered in foreign commerce. Statoil, 214 F.3d at 428. The Second Circuit in the Christie's Auction House litigation, Kruman v. Christie's Int'l PLC, 284 F.3d 384 (2d Cir. 2002), reached the opposite conclusion. The D.C. Circuit in Empagran aligned itself close to Kruman, holding that the foreign plaintiffs' claims could be heard in U.S. antitrust courts. Empagran, S.A. v. F. Hoffman-LaRoche, Ltd., 315 F.3d 338, 350 (D.C. Cir. 2003).

129. Empagran, 542 U.S. at 161-62 (interpreting 15 U.S.C. $\$ 6(a)(1)$ ). Section 6(a)(1) literally requires that conduct is within the purview of a U.S. antitrust court only if such conduct has a direct, substantial, and reasonably foreseeable effect (A) on trade or commerce which is not trade or commerce with foreign nations, or on import trade or import commerce with foreign nations; or (B) on export trade or export commerce with foreign nations, of a person engaged in such trade or commerce in the United States.

130. See Empagran, 542 U.S. at 162 (interpreting 15 U.S.C. § 6(a)(2) (2000)). Section $6(\mathrm{a})(2)$ literally requires that, once a plaintiff has demonstrated the requisite effect to meet the first element of the FTAIA, the plaintiff prove also that such effect gives rise to a claim under the provisions of sections 1 to 7 of this title, other than this section. If sections 1 to 7 of this title apply to such conduct only because of the operation of paragraph (1)(B), then sections 1 to 7 of this title shall apply to such conduct only for injury to export business in the United States.

131. Empagran, 542 U.S. at 175. 
The conduct must have given rise to "the" claim that formed the basis of their lawsuit. ${ }^{132}$

Two primary rationales support that interpretation. First, the principle of prescriptive comity requires construing ambiguities in the FTAIA "to avoid unreasonable interference with the sovereign authority of other nations."133 Second, the Empagran Court was convinced from a read of the language and legislative history of the FTAIA that the statute narrowed, rather than broadened, the scope of extraterritorial application of the U.S. antitrust laws $v i s-a$-vis the state of the law before its enactment. ${ }^{134}$

Justices Scalia and Thomas concurred in the judgment only. They would have relied solely on the text of the FTAIA, interpreted in the light of "the principle that statutes should be read in accord with the customary deference to the application of foreign countries' laws within their own territories"- that is, the prescriptive comity canon ${ }^{135}$

\section{International Comity Ramifications}

Under the prescriptive comity rationale, the Court paid exceptional respect to concerns for the possible harm to international comity from U.S. antitrust courts' jurisdictional overreaching. The presence in the litigation of several foreign government amici figured prominently in the opinion. ${ }^{136}$

The emphasis on comity was an about-face from the Court's opinion

132. Id. at 174. No confusion exists as to this part of the Court's holding. See, e.g., Sniado v. Bank Austria A.G., 378 F.3d 210 (2d Cir. 2004), on remand from 542 U.S. 917 (2004), vacating and remanding in light of Empagran, 542 U.S. 155 (2004). In Sniado, the plaintiffs had not alleged any nexus between a domestic effect of overseas conduct and their foreign injuries. The Second Circuit held that in light of Empagran, the complaint must be dismissed. Id. at 212-13.

133. Empagran, 542 U.S. at 164 (citing McCulloch v. Sociedad Nacional de Marineros de Honduras, 372 U.S. 10 (1963))

On prescriptive comity generally, see Hartford Fire Ins. Co. v. California, 509 U.S. 764, 812-22 (1993) (Scalia, J., dissenting in part). Under this doctrine, "'an act of congress ought never to be construed to violate the law of nations if any other possible construction remains." 'Id. at 814-15 (quoting Murray v. The Schooner Charming Betsey, 6 U.S. (2 Cranch) 64, 118 (1804) (Marshall, C.J.). "Though it clearly has constitutional authority to do so, Congress is generally presumed not to have exceeded those customary internationallaw limits on jurisdiction to prescribe." Id . at 815. See also generally Pamela Karten Bookman, Solving the Extraterritoriality Problem: Lessons from the Honest Services Statute, 92 VA. L. REv. 749, 755-59 (2006) (describing the prescriptive comity doctrine).

134. Empagran, 542 U.S. at 169. The opinion qualified this discussion as helpful "to those who find legislative history useful." Id. at 163. Writing for six Justices, Justice Breyer appears to be referring in this passage to a concurrence in which Justice Scalia, joined by Justice Thomas, concurred in the judgment by relying solely on the text of the statute and canons of construction. See id. at 176 (Scalia, J., concurring). See generally Max Huffman, Review Essay: Using All Available Information, 25 Rev. Litig. 501, 506 (2006) (noting the regularity with which Justices Breyer and Scalia concur in each other's opinions, advancing their own views of the statutory interpretive process).

135. Empagran, 542 U.S. at 176.

136. See id. at 167-69 (citing to briefs filed by the governments of Germany, Canada and Japan). 
eleven years previous in Hartford Fire. ${ }^{137}$ The Court held in that case, in an analysis turning on the common-law effects test, that a U.S. court should exercise jurisdiction over a claim of overseas conspiracies with effects in U.S. markets. ${ }^{138}$ "[E]ven assuming that in a proper case a court may decline to exercise Sherman Act jurisdiction over foreign conduct ...., international comity would not counsel against exercising jurisdiction in the circumstances alleged here."139 By contrast, in Empagran, all eight voting Justices agreed that comity considerations were controlling. But the Empagran Court did not explicitly cast doubt on the Hartford Fire rule. ${ }^{140}$ What the Court did do was elevate the comity question from an afterthought in Hartford Fire to a preeminent decision rationale in Empagran. ${ }^{141}$

The fulcrum of the prescriptive comity analysis in Empagran was this: stepping on toes internationally is acceptable to protect domestic commerce. It is not acceptable in order to protect wholly foreign commerce. ${ }^{142}$ The opinion contrasted the case of application of U.S. antitrust laws to foreign commerce to redress domestic injury with the same overseas application to redress foreign injury. ${ }^{143}$ In each situation, extraterritorial antitrust jurisdiction raises comity concerns by "interfer[ing] with a foreign nation's ability independently to regulate its own commercial affairs."144 In the case of domestic injury, the Court held it is "reasonable" to apply our laws to regulate the foreign conduct. ${ }^{145}$ But in the case of foreign injury, the Court held "the justification for that interference" with the foreign nation's regulatory authority "seems insubstantial."146

137. 509 U.S. 764. See Buxbaum, supra note 6, at 1095, 1101 (discussing Empagran as evidence of a "renewed interest on the part of the Supreme Court in using principles of comity to confine the extraterritorial reach of U.S. antitrust law").

138. Hartford Fire, 509 U.S. at 798-99.

139. Id.

140. Cf. McBee v. Delica Corp., 417 F.3d 107 (1st Cir. 2005) (relying on both Empagran and Hartford Fire).

141. Compare Buxbaum, supra note 6, at 1102 (Empagran "signals acceptance of the notion that comity operates actually to limit the reach of U.S. law to foreign conduct"), with Wurmnest, supra note 3, at 218 (calling Hartford Fire a "near death blow to comity"); Diamond, supra note 12, at 814-15 (interpreting Hartford Fire to relegate comity principles to a circumstance of true conflict between a foreign regime and U.S. law). The importance of comity concerns in extraterritorial commercial regulation has received significant scholarly attention. See, e.g., Podgor, supra note 1, at 84 (arguing that comity concerns should receive more attention, and those concerns raise the question of the location of the social harm to be remedied).

142. Buxbaum, supra note 6, at 1100 ("the principle of non-interference is not absolute. Statutes must be construed to prevent unreasonable interference . . . but, as the Court notes, sometimes interference with foreign sovereign authority is justified").

143. F. Hoffman-LaRoche, Ltd. v. Empagran, S.A., 542 U.S. 155, 165 (2004). Cf. Edward D. Cavanagh, The FIAIA and Subject Matter Jurisdiction over Foreign Transactions Under the Antitrust Laws: The New Frontier in Antitrust Litigation, 56 SMU L. Rev. 2151, 2159-80 (2003) (listing "concrete factual scenarios in which jurisdictional issues arise"combinations of foreign or domestic conduct and foreign or domestic harm).

144. Empagran, 542 U.S. at 165.

145. Id. at 165. See Buxbaum, supra note 6, at 1103.

146. Empagran, 542 U.S. at 165. One commentator, addressing the Empagran Court's prescriptive comity analysis, concludes that it foreordained the D.C. Circuit's holding on remand. Edward D. Cavanagh, The FTAIA and Empagran: What Next 58 SMU L. REv. 
Empagran is a definitive modern statement of a rule announced previously in cases such as Matsushita Electric Industries Corp. v. Zenith Radio Corp. ${ }^{147}$ that the policies of the U.S. antitrust scheme support the protection of U.S. commerce. Because, as this Article has previously argued, the prudential standing inquiry exists to ensure private litigation furthers the policies of the antitrust laws, Empagran should be read to teach that comity considerations are an analysis that must be injected into the prudential standing inquiry. ${ }^{148}$

\section{Statutory Interpretation}

The Court rejected the lower court's literalist reading of the FTAIA. ${ }^{149}$ This rejection is surprising because of the apparent ease with which it was reached. The literalist interpretation hews closely to the plain language of the FTAIA. Section 6(a)(1) permits suit in a U.S. antitrust court if the complained-of conduct "gives rise to a claim" under the substantive antitrust laws. ${ }^{150}$ The Court adopted the rule advanced by defendants, holding the conduct must give rise to the claim - that of the plaintiff suingrather than just any claim. ${ }^{151}$ Neither the Court nor the concurrence made any effort to construe away Congress's choice of the indefinite article "a," noting respondents' "linguistic logic."152 It acknowledged "respondents' linguistic arguments might show that respondents' reading is the more natural reading of the statutory language."153 In concurrence,

1419, 1437 (2005). According to this argument, when the D.C. Circuit analyzed plaintiffs' claims under the Empagran exception, it was required to hold no subject-matter jurisdiction exists because of comity concerns. Id. at 1434 . That analysis overlooks two things: (1) the Court's use of the word "reasonable" to describe the degree of interference with foreign nations' sovereign authority over matters implicating their own domestic commerce (Empagran, 542 U.S. at 165-66), and (2) the continuing vitality of the Court's decision in Hartford Fire. Far from condemning all efforts to bring claims of harm in foreign commerce in U.S. antitrust courts, one can infer from Empagran a weighing of the degree of impingement on foreign sovereignty against the interests of the United States in the enforcement of its laws. See Empagran, 542 U.S. at 165 ("application of our antitrust laws to foreign anticompetitive conduct is nonetheless reasonable, and hence consistent with principles of prescriptive comity, insofar as they reflect a legislative effort to redress domestic antitrust injury that foreign anticompetitive conduct has caused"). The latter is a question of the degree to which the harm plaintiffs allege reflects an effect on U.S. commerce.

147. 475 U.S. 514 (1986),

148. See supra notes $1-12$ and accompanying text.

149. Empagran, 542 U.S. at 173-75.

150. 15 U.S.C. \$ 6(a)(2) (2005). See supra notes 76-91 and accompanying text (describing the FTAIA). The literalist reading had convinced six of nine federal court of appeals judges to consider it. See Empagran, 315 F.3d 338; Kruman v. Christie's, 284 F.3d 384 (2d Cir. 2002); Der Norske Stats Oljeselskep As v. Heeramac VOF, 241 F.3d 420 (5th Cir. 2001) (Higginbotham, J., dissenting).

151. Empagran, 542 U.S. at 173-75.

152. Id. at 174 .

153. Id. The majority was comfortable that notions of prescriptive comity overcame the statute's plain language. Id. at 175 (majority opinion). Again, an argument has been made that this reasoning precluded a decision for the plaintiffs on remand. "Clearly, plaintiffs' alternative theory" - what this article has termed their theory of worldwide interdependence- - "would expand antitrust jurisdiction, since they have cited no decisions that upheld Sherman Act jurisdiction over foreign transactions on their ... theory before the FTAIA's enactment." Cavanagh, supra note 146, at 1434. That analysis ignores the story of extra- 
Justice Scalia-famous for his "textualist" statutory interpretive philosophy ${ }^{154}$ _ "concur[red] in the judgment of the Court because the language of the statute is readily susceptible to the interpretation the Court provides." 155

\section{What the FTAiA Does Not Do}

The statute, as interpreted in Empagran, does not establish a brightline rule prohibiting suits by foreign plaintiffs injured in foreign commerce. ${ }^{156}$ The Empagran Court declined to address plaintiffs' worldwide conspiracy argument:

We have assumed that the anticompetitive conduct here independently caused foreign injury; that is, the conduct's domestic effects did not help to bring about that foreign injury. . . . Respondents contend that, because vitamins are fungible and readily transportable, without an adverse domestic effect (i.e., higher prices in the United States), the sellers could not have maintained their international price-fixing arrangement and respondents would not have suffered their foreign injury. ... .

The Court of Appeals, however, did not address this argument . . ., and, for that reason, neither shall we. ${ }^{157}$

The avenue of argument that the Court left for plaintiffs to allege their harm in foreign commerce was caused by the effects of the defendant's conduct in U.S. commerce is the Empagran exception. And the Court explicitly declined to define its contours. ${ }^{158}$

The Court's approach in Empagran can be likened to the creation of a per se rule at substantive antitrust law. When circumstances-in this case,

territoriality of commerce, remarked numerous times by courts and commentators, over the decades since the FTAIA was enacted in 1982. Increasing interdependence of world markets increases the likelihood that a foreign harm will flow from a domestic effect. The fact that plaintiffs prior to 1982 had been unsuccessful making those allegations does little to inform the likelihood of success of that argument on remand in Empagran II, and even less to inform the likelihood of success of that argument under the Empagran exception going forward.

154. See generally Antonin Scalia, A Matter of Interpretation: Federal Courts And the Law (1997). See also Huffman, supra note 134.

155. Empagran, 542 U.S. at 176 (Scalia, J., concurring). Justice Scalia was swayed by principles of "deference to the application of foreign countries' laws within their own territories." Id.

156. Id. at 175 .

157. Id.

Throughout the opinion the Court took great pains to make clear that it "base[d] our decision" on the assumption that "the adverse foreign effect is independent of any adverse domestic effect." Id. (This caveat was repeated many times in some form or another in the opinion.) See, e.g., id. at 165 ("Why is it reasonable to apply this law to conduct that is significantly foreign insofar as that conduct causes independent foreign harm and that foreign harm alone gives rise to the plaintiff's claim?").

158. See In re Monosodium Glutamate Antitrust Litig., No. Civ. 00MDL1328, 2005 WL 1080790, at *1 (D. Minn. May 2, 2005) ("The Empagran Court expressly declined to address the issue presented in this case: whether subject matter jurisdiction exists when a plaintiff's foreign injury is allegedly linked to the domestic effects of the allegedly anticompetitive conduct."). 
the "insubstantial" nature of any arguments supporting interference in foreign sovereigns' right to regulate their own markets-demonstrate that no grounds exist on which extraterritorial application would be appropriate, the Court was willing to preclude inquiry on the question in future cases. ${ }^{159}$ But in the greater range of cases, judicial experience is not sufficiently complete to permit a conclusion that extraterritorial application is per se inappropriate. ${ }^{160}$ Those cases remain subject to the Empagran exception-a modern extraterritorial rule of reason. ${ }^{161}$

The flexible rule in Empagran recognized that the state of multinational commerce has not remained constant since the FTAIA was enacted in 1982. It will continue to develop going forward. A rule imposing an inflexible approach as to the geographic scope of courts' extraterritorial reach would not accommodate changing circumstances. ${ }^{162}$ In the Empagran exception, the Court permitted ongoing analysis of the kinds of harms cognizable under U.S. antitrust laws. ${ }^{163}$

\section{What Really Happened in EMPagran}

Questions remain on what procedural ground the Empagran Court found fault with the lower court's analysis. Three possibilities include subject-matter jurisdiction, failure to state a claim, and prudential standing. The Seventh Circuit held prior to Empagran the FTAIA analysis is not an element of the substantive offense, ${ }^{164}$ and the Empagran Court did

159. Cf. HovenKAmP, supra note 3 , at 117-18 (describing circumstances justifying the imposition of per se rules under the substantive law).

160. $C f$. id. at 118 (noting that the creation of a per se rule is a judgment that requires sufficient prior experience). Professor Hovenkamp argues that antitrust law does better with fewer per se rules. Id. at 308.

161. Cf. Cavanagh, supra note 143, at 2154 (describing the Ninth Circuit's decision in Timberlane as creating a "jurisdictional rule of reason"). But see Empagran, 542 U.S. at 168 (noting in dictum courts should not evaluate extraterritoriality considerations case-bycase); Cavanagh, supra note 143, at 2154 (same); Wurmnest, supra note 3, at 221 (same).

162. Cf. HovenKamp, supra note 3, at 116-20 (describing the problems produced by the doctrine of stare decisis and the antitrust per se rule). "Stare decisis has effectively created a ratchet for the per se rule, permitting courts to move in one direction but not the other." Id. at 118 .

163. In fact, decisions since Empagran have held allegations of worldwide interdependence sufficient to meet the Empagran exception and to survive motions to dismiss. See infra notes 193-226 and accompanying text. Courts before Empagran had only rarely been faced with allegations of a truly interdependent worldwide cartel. See Connor, supra note 18, at 7-17 (arguing the vitamins cartel was sui generis); JOHN M. CONNOR, Private INTERnational Cartels: Effectiveness, Welfare, and Anticartel Enforcement 1 (2003) ("The international cartels discovered and prosecuted since 1995 are qualitatively different from those operating during the interwar period. They are truly global cartels and as such represent the ultimate stage in the evolution of the cartel as a form of business enterprise.") [hereinafter Private InTernational CARTels]. Empagran made explicit that no reason exists why sufficient allegations of worldwide interdependence could not permit a suit alleging foreign harm to proceed. Empagran, 542 U.S. at 173-75. And economic theory, discussed above, supports those holdings. See supra notes 106-08 and accompanying text. But see eMag Solutions LLC v. Toda Kogyo Corp., No. C02-1611 PJH, 2005 WL 1712084 (N.D. Ca. July 20, 2005) (substantial allegations of worldwide interdependence held insufficient).

164. See United Phosphorus, Ltd. v. Angus Chem. Co., 322 F.3d 942, 950 (7th Cir. 2003). 
nothing to disturb that holding or other lower-court holdings on which it relied-so Civil Rule 12(b)(6) does not explain the Empagran result. ${ }^{165}$ According to one commentator: "Strangely enough, in a case that is generally discussed as being about subject matter jurisdiction, Justice Breyer used the term only once, and that was in quoting a treatise." 166 The better understanding of Empagran is that it is a recognition of the role of the prudential standing analysis in interpreting the FTAIA.

The Empagran Court did not mention, let alone discuss or decide, the standing arguments decided by the D.C. Circuit, discussed by other courts and commentators, pressed by the parties and amici, and which this Article contends best explain the result. The reasons for that failure are unclear. ${ }^{167}$ The standing analysis was ripe for decision in Empagran. The question had been addressed (and the standing argument rejected) by the court of appeals below. ${ }^{168}$ It had been fully briefed by the parties and amici and was the subject of argument by the United States as amicus. ${ }^{169}$ Nonetheless, good reason exists to understand Justice Breyer's opinion in Empagran as following the antitrust standing rationale. ${ }^{170}$

165. See Huffman, supra note 8 .

166. Diamond, supra note 12 , at 840 (arguing the opinion might be read as relying on a 12(b)(6) standard).

167. The opinion's author, Justice Breyer, has been called the Court's primary antitrust thinker. See Huffman, supra note 134, at 514 n.49. Certainly he was able to follow the antitrust standing argument and apply it if he preferred. Other Members of the Empagran Court had written important opinions in standing cases. See, e.g., Associated Gen. Contractors of Cal. v. Cal. State Council of Carpenters, 459 U.S. 519, 520, 555 (1983); Blue Shield of Va. v. McCready, 457 U.S. 465, 485 (1982) (Rehnquist, J., dissenting); id. at 493 (Stevens, J., dissenting).

168. See Empagran S.A. v. F. Hoffman-LaRoche Ltd., 315 F.3d 338, 357-59 (D.C. Cir. 2003).

169. At oral argument by the government amici in support of petitioners, the standing argument received a somewhat ignominious reception. Then-acting Assistant Attorney General R. Hewitt Pate argued, "with respect to the foreign-incurred injuries, [the foreign plaintiff] must show injury by reason of that which makes the conduct illegal, and since Alcoa in [1945], and certainly under Hartford, it is the effect on U.S. commerce that make the conduct the concern of the Sherman Act." Transcript of Oral Argument at 19, Empagran, 542 U.S. 155 (No. 03-724) (citing United States v. Aluminum Co. of Am., 148 F.2d 416 (1945); Hartford Fire Ins. Co. v. California, 509 U.S. 764 (1993)). See also Brief for the United States as Amicus Curiae Supporting Petitioners, Empagran, 542 U.S. 155 (2004) (No. 03-724); Brief of the Chamber of Commerce of the United States and Organization for International Investment as Amici Curiae Supporting Petitioners, Empagran, 542 U.S. 155 (2004) (No. 03-724). Justice Stevens - the author of Associated Gen. Contractors, 459 U.S. 519 (1983), and an important dissent in Blue Shield of Va. v. McCready, 457 U.S. 465, 493 (1982)—queried in response: "I don't follow the [argument]." Transcript of Oral Argument at 19, Empagran, 542 U.S. 155 (2004) (No. 03-724).

170. One commentator has suggested that the failure to rely on standing as a decision rationale reflects a desire to let the issue percolate further before it becomes the basis for decision. Cavanagh, supra note 146, at 1431. That explanation is misguided for two reasons. First, the antitrust injury doctrine was established in Brunswick without significant underlying percolation in the courts of appeals. The primary discussion of antitrust standing as a decision principle had come from an article the year before by Professor Areeda. Areeda, supra note 22, at 1130-36. By contrast, when Empagran was decided, not only was antitrust standing doctrine well established, its application in the extraterritoriality framework had been analyzed by lower courts, including the D.C. Circuit in Empagran, and by noted commentators. See Empagran, 315 F.3d at 357-59; Der Norske Stats Oljeselskep As v. Heeramac VOF, 241 F.3d 420, 431 n.32 (5th Cir. 2001); deAtucha v. Commodity Ex- 
The failure to address standing reflects the narrowness of the Court's opinion. Foreign harm with no connection to an effect on U.S. commerce - the only explicit application of the opinion-does not raise difficult prudential issues. The Court had no need to rely on a prudential doctrine. That standing doctrine underlies Empagran is made clear by a structural analysis of the FTAIA and by examining three features of the Court's opinion interpreting the statute.

\section{The FTAIA Preserved the Standing Doctrine}

The Second Circuit in Kruman noted the essential distinction between the substantive provisions of the U.S. antitrust scheme-what the FTAIA refers to as "sections 1 to 7 of this title" 171 _and the right of action provisions, which include Clayton 4, the basis for the antitrust standing inquiry. ${ }^{172}$ Although it held the FTAIA permitted jurisdiction over the plaintiffs' claims, the Second Circuit's careful analysis of the structure of the U.S. antitrust laws and its broad extraterritoriality holding did nothing to prejudice defendants' abilities to argue a lack of standing in that case. ${ }^{173}$

change, Inc., 608 F. Supp. 510 (S.D.N.Y. 1985); 1 WALLER, supra note 84, § 9.7 (noting the relevance of standing issues in the FTAIA context); Cavanagh, supra note 143, at 2187-88. Second, the Court regularly signals its refusal to decide an issue not decided by the courts below-in fact, it refused to define the scope of the Empagran exception, preferring to let the D.C. Circuit decide that issue first-but it did not do so with regard to standing. See Empagran, 542 U.S. at 175. See also, e.g., Anza v. Ideal Steel Supply Corp., 126 S. Ct. 1991, 1999 (2006) ("We decline to consider Ideal's § 1962(a) claim without the benefit of the Court of Appeals' analysis ....").

171. 15 U.S.C. $\S 6(a)(2000)$.

172. Cavanagh, supra note 143 , at 2175 . This distinction was lost on the D.C. Circuit in Empagran.

173. Kruman v. Christie's Int'l PLC, 284 F.3d 384, 403 (2d Cir. 2002) (remanding to the trial court to decide the standing issue in the first instance). Determining what might have happened in Kruman on remand may be a process of reading tea leaves, but there is ample indication in the district court's opinion that it would have dismissed plaintiffs' claims on remand on the grounds of antitrust standing. Judge Kaplan of the Southern District of New York observed the distinction on which the Second Circuit relied between illegal conduct and the private right to a remedy:

[I]t is perfectly appropriate for the United States to punish the conspiracythe formation and continuation of the illicit agreement-because it took place in substantial part in this country .... But it would be appropriate for the United States to provide remedies for injuries suffered in consequence of overt acts that occurred outside this country only if those acts, either individually or perhaps collectively, had direct, substantial and reasonably foreseeable effects here that caused the injuries to be remedied.

Kruman v. Christie's Int'l PLC, 129 F. Supp. 2d 620, 625-26 (S.D.N.Y. 2001). Judge Kaplan also cited provisions in the legislative history of the FTAIA demonstrating the concern for the location of the particular plaintiffs' injuries and the nexus between the effect and the injury. Kruman, 129 F. Supp. 2d at 624-25 (citing H.R. ReP. No. 97-686, at 7-8 (1982)). Judge Kaplan surely would not have taken long on remand to discover in that same legislative history the express intent to preserve the doctrines of antitrust standing and antitrust injury. See H.R. ReP. No. 97-686, at 11 (1982), as reprinted in 1982 U.S.C.C.A.N. 2487, 2496 ("Conduct which has an anticompetitive effect which impinges only on defendants [plaintiffs] located in foreign nations and which has a neutral or procompetitive domestic effect" does not give rise to standing under the antitrust laws.). 
The Kruman analysis is a highly defensible interpretation of the FTAIA in light of a broader understanding of the U.S. antitrust scheme. The Kruman court understood the FTAIA as a jurisdictional provision that spoke to the type of conduct forbidden-conduct that violates the U.S. antitrust laws-rather than to the type of plaintiff that may bring suit to remedy harm caused by that conduct, a question answered by Clayton 4. ${ }^{174}$ That understanding of the FTAIA relies on a separation in the U.S. antitrust scheme between the substantive, jurisdictional provisions and the right of action provision contained in Clayton $4 .{ }^{175}$ Under the Kruman approach, factors to be considered in the extraterritoriality analysis are part of a private plaintiff's standing argument under Clayton 4an approach reminiscent of the Third Circuit's pre-FTAIA decision in Mannington Mills, Inc. v. Congoleum Corp. ${ }^{176}$

Other courts in modern FTAIA litigation have ignored the careful distinction in the antitrust laws between the conduct standards and the private right of action provision, specifically rejecting arguments that the schemes should be treated separately. ${ }^{177}$ For example, the lower court in Empagran treated the FTAIA as a hybrid provision that spoke to both the type of conduct over which suit is cognizable and the type of plaintiff that is permitted to sue. ${ }^{178}$

Two strong arguments refute the hybrid approach to the FTAIA. First, the FTAIA gives no indication, in its text or in its legislative history, of any intent to supplant the body of antitrust standing doctrine that has grown up around interpretations of Clayton $4 .{ }^{179}$ The legislative history explicitly recognized the preservation of "existing concepts of antitrust injury or antitrust standing." 180 Second, the FTAIA applies equally in

174. Kruman, 284 F.3d at 399-400.

175. Clayton Act $\S 4,15$ U.S.C. $§ 15$ (2000 \& Supp. 2005).

176. See generally Huffman, supra note 8 .

177. Empagran S.A. v. F. Hoffman-La Roche Ltd., 315 F.3d 338, 350-51 (D.C. Cir. 2003) (calling the structural argument "plausible but ultimately unconvincing").

178. See id. at 358 (satisfying FTAIA implies plaintiffs were the appropriate plaintiffs to bring suit).

The FTAIA does contain a bare glimmer of support for that interpretation in its explicit textual reference to the type of exporter plaintiff that must suffer harm to permit extraterritorial jurisdiction: "sections 1 to 7 of this title shall apply to such conduct only for injury to export business in the United States." 15 U.S.C. § 6(a) (2000). But that textual support, at most, is a limitation on standing applicable only to a narrow class of exporter plaintiffs. It cannot support reading the FTAIA to address the antitrust standing inquiry more broadly. Under the expressio unius et exclusio alterius canon of construction, the explicit reference to exporter plaintiffs is evidence that the FTAIA does not address the standing inquiry for other plaintiffs.

179. See Memorandum from the Antitrust Modernization Comm. to All Comm'rs, Supplemental International Antitrust Discussion Memorandum-FTAIA Issue 5 (July 21, 2006), available at http://www.amc.gov/pdf/meetings/Intl-FTAIASuppMemo060721circ.pdf ("The legislative history indicates that Congress did not intend to alter the issue of plaintiffs' standing."). Cf. de Atucha v. Commodity Exch., Inc., 608 F. Supp. 510, 517 n.20 (S.D.N.Y. 1985) (holding the FTAIA "not applicable to the instant action (because it relates to jurisdiction, not standing)").

180. H.R. ReP. No. 97-686, at 11 (1982), as reprinted in 1982 U.S.C.C.A.N. 2487, 2496. 
actions brought by the government. ${ }^{181}$ This is so although the antitrust enforcement agencies are not required to establish standing to bring suit over substantive antitrust violations. ${ }^{182}$ If satisfying the FTAIA precludes a standing analysis, the statutory inquiry resolves the standing question even for those government plaintiffs that need not establish standing. The opposite side of the same coin is that the extraterritoriality analysis under the FTAIA is redundant to an analysis under Clayton 4, violating the principle that statutes should be construed to avoid redundancy. ${ }^{183}$ The better understanding is that the FTAIA speaks to conduct of concern, and Clayton 4 governs all aspects of a private plaintiff's right to sue.

\section{Standing Decision Principles Control the FTAIA Analysis}

Three features of the Empagran Court's interpretation of the FTAIA justify reading it as a standing opinion, interpreting the private plaintiff's right to sue under Clayton 4, even if couched as a jurisdictional holding under the FTAIA. ${ }^{184}$ First, the Court relied on California v. American Stores Co. ${ }^{185}$ to support the conclusion that cases involving the United States as a plaintiff do not inform the extraterritoriality analysis for private plaintiffs. Second, the Court emphasized doctrine, including comity considerations and the first-principles deterrence rationales, that are best suited to a malleable standing analysis. Third, the Court failed to overrule Hartford Fire. ${ }^{186}$

181. See U.S. Dep't of Justice and Fed. Trade Comm'n, Antitrust Enforcement Guidelines FOR INTERNATIONAL OpERATIONS $\$ \S 3.12,3.121$ (Apr. 1995), available at http://www.usdoj.gov/atr/public/guidelines/internet.htm ("To the extent that conduct in foreign countries does not 'involve' import commerce but does have an 'effect' on either import transactions or commerce within the United States, the Agencies apply the 'direct, substantial, and reasonably foreseeable' standard of the FTAIA.").

182. See, e.g., 15 U.S.C. $\$ 4$ (granting to the Department of Justice power to enforce substantive provisions of the Sherman Act). See also F. Hoffman-LaRoche, Ltd. v. Empagran, S.A., 542 U.S. 155, 170-71 (2004).

183. See Conn. Nat'l Bank v. Germain, 503 U.S. 249, 256 (1992) (O'Connor, J., concurring).

184. This explanation is similar to the treatment given to standing doctrine in briefing by the United States as amicus in Empagran. The United States argued that the standing question was subsumed into the FTAIA. See Government D.C. Cir. Brief, supra note 102.

185. 495 U.S. 271 (1990).

186. One implication of this interpretation is that Justice Scalia in concurrence, who had dissented from the Court's failure to recognize comity limitations on the extraterritorial reach of the antitrust laws in Hartford Fire, Hartford Fire Ins. Co. v. California, 509 U.S. 764, 817-20 (1993), misunderstood the actual import of the majority's Empagran opinion. After his vigorous dissent in Hartford Fire, it is unlikely that a decision in line with the Hartford Fire approach of treating comity as a prudential matter-what this Article argues is placing the comity concern into the standing framework-would command a concurrence in any of its reasoning by Justice Scalia. Id. It is possible that treating what is essentially a standing analysis as a matter of interpretation informed by notions of prescriptive comity might have been a political compromise to avoid a fractured opinion like that in Hartford Fire. 


\section{a. Public Versus Private Enforcement}

The distinction between public and private enforcement and the citation to American Stores make sense in a standing analysis. They do not make sense in the context of subject-matter jurisdiction. As the American Stores Court noted, private plaintiffs "must have standing . . . in order to obtain relief." 187 But "[i]n a Government case the proof of the violation of law may itself establish sufficient public injury to warrant relief."188 This authority distinguished Timken Roller Bearing Co., National Lead Co., and American Tobacco Co., ${ }^{189}$ all pre-FTAIA examples of extraterritorial application of the U.S. antitrust laws. ${ }^{190}$ Because those cases were brought by the United States, not by private plaintiffs, they did not speak to the standards for extraterritoriality in private litigation.

The FTAIA itself does not support that conclusion. The statute makes no distinction between public and private plaintiffs. ${ }^{191}$ It applies whether the suit is one by the government as a regulator or a private plaintiff seeking compensation for harm suffered as a market participant. In fact, the FTAIA has a direct analog in the FTC Act, which has no private right of action like Clayton 4. ${ }^{192}$ There also is no distinction between public enforcement and private enforcement in the substantive definition of an antitrust claim. ${ }^{193}$ The American Stores distinction between public and private enforcement is relevant because only the private plaintiff finds its right of action in Clayton 4 and must establish standing to sue. Invoking the public/private distinction, and American Stores, demonstrates reliance on a prudential standing inquiry.

More, the Empagran Court noted different incentives between private plaintiffs and government plaintiffs. ${ }^{194}$ This reflects an invocation of the optimization goals that this Article has argued are embedded in the prudential standing inquiry. ${ }^{195}$ The FTAIA, by contrast, does not provide a warrant for considering the differential incentives among different classes of litigants invoking its language.

\section{b. Reliance on Previously Unsung Rationales}

Reliance on comity concerns and deterrence rationales as decision principles makes more sense in a standing analysis. One court recently has

187. American Stores, 495 U.S. at 296 (discussing standing in the context of the private injunctive remedy under Clayton Act $\$ 16)$.

188. Id. at 295 .

189. Timken Roller Bearing Co. v. United States, 341 U.S. 593 (1951); United States v. Nat'l Lead Co., 332 U.S. 319 (1947); United States v. Am. Tobacco Co., 221 U.S. 106 (1911).

190. F. Hoffman-La Roche LTD v. Empagran, S.A., 542 U.S. 155, 170 (2004).

191. See generally 15 U.S.C. $\S 1-7$ (2000).

192. See 15 U.S.C. $\$ 45(\mathrm{a})(3)$.

193. Id.

194. Empagran, 542 U.S. at 171 (citing Joseph P. Griffin, Extraterritoriality in U.S. and EU Antitrust Enforcement, 67 AnTitrust L.J. 159, 194 (1999)).

195. See supra notes 57-68 and accompanying text. 
reject[ed] the notion that a comity analysis is part of subject matter jurisdiction. Comity considerations ... are properly treated as questions of whether a court should, in its discretion, decline to exercise subject matter jurisdiction that it already possesses. Our approach to each of these issues is in harmony with the analogous rules for extraterritorial application of the antitrust laws. ${ }^{196}$

That approach, taken by the First Circuit in McBee v. Delica Corp., is highly reminiscent of the Third Circuit's Mannington Mills decision. ${ }^{197}$

The same is true for first-principles deterrence rationales. Comity and deterrence are not grounded anywhere in the text of the antitrust laws, and, in particular, are not found in the text of the FTAIA. Congress left to the courts the question whether and how to invoke deterrence principles. In particular, the inverse deterrence argument, which received much attention in Empagran, did not exist when the FTAIA was enacted in 1982. The amnesty program on which it is based has been in existence only since $1993 .{ }^{198}$

The prudential standing inquiry is an inquiry in which the common law always has been employed to advance the doctrine. ${ }^{199}$ It is an inquiry that permits courts to address principles not set down by Congress in statutory text when those principles inform the question what plaintiff is an efficient vindicator of the purposes of the antitrust laws. Reliance on extra-statutory principles governing entitlement to suit is best understood as reliance on standing doctrine.

A contrary explanation might be that prescriptive comity principles speak to interpretations of the antitrust laws, including the FTAIA. That is the most reasonable understanding of Justice Scalia's concurrence in Empagran. Of course, that explanation says nothing about the emphasis on deterrence concerns, which is not supportable as a technique of interpretation. Reliance on deterrence principles can be justified only by looking outside the text of the FTAIA. Also, prescriptive comity doctrine is not a tool for parsing statutory language. It speaks generally to the need to interpret statutes to avoid offending foreign sovereign authority. A principled approach to interpretation could respect prescriptive comity doctrine while placing the comity concern in the appropriate box in the statutory scheme. That box is Clayton 4, not the FTAIA.

196. McBee v. Delica Co., 417 F.3d 107, 111 (1st Cir. 2005) (referring to Hartford Fire Co. v. California, 509 U.S. 764 (1993)).

197. Compare id. with Mannington Mills, Inc. v. Congoleum Corp., 595 F.2d 1287 (3d Cir. 1979).

198. See Corporate Leniency Policy, supra note 80.

199. See Associated Gen. Contractors of Cal., Inc. v. Cal. State Council of Carpenters, 459 U.S. 514, 533 (1983) ("Congress simply assumed that antitrust damages litigation would be subject to constraints comparable to well-accepted common-law rules applied in comparable litigation"); Blue Shield of Va. v. McCready, 457 U.S. 465, 477 (1982) (comparing standing doctrine to common-law tort causation). $C f$. Frank H. Easterbrook, Is There a Rachet in Antitrust Law?, 60 Tex. L. Rev. 705, 706 (1982) (noting that the antitrust laws are interpreted in the nature of common law analysis). 


\section{c. Reconciling Hartford Fire}

The coexistence of the rule in Hartford Fire with the broader definition of the comity consideration announced in Empagran is further evidence the Empagran Court relied on a prudential standing inquiry. Hartford Fire defined the comity consideration narrowly as a subject-matter jurisdiction question. ${ }^{200}$ After Hartford Fire, commentators and courts generally understood comity concerns to preclude a finding of subject-matter jurisdiction only in the case of a direct conflict between the foreign sovereign's laws and the laws of the United States.

Empagran was an about-face on the comity rationale. The about-face can be justified by reference to standing principles, which explanation also reconciles Empagran with Hartford Fire. Hartford Fire stated a narrow comity analysis for subject-matter jurisdiction purposes, explicitly leaving for another day the prudential question. ${ }^{201}$ Empagran broadened the Hartford Fire approach to the comity principle-this time, as a prudential matter.

\section{PRUDENTIAL STANDING ANALYSIS DEFINES THE EMPAGRAN EXCEPTION}

Courts interpreting the FTAIA since Empagran have treated the Empagran exception as a question of the degree of nexus between the effect on domestic U.S. commerce alleged and the harm suffered by the plaintiff in foreign commerce. According to the D.C. Circuit on remand, in Empagran II-a decision that has emerged as the leading authority on the Empagran exception-a plaintiff with a foreign harm may sue in a U.S. antitrust court if a domestic effect of the conduct proximately caused the foreign harm. ${ }^{202}$ The simple proximate cause analysis, though, is notoriously slippery. ${ }^{203}$ Lacking a clear statement of decision principles, the Empagran exception has produced as much confusion as existed prior to Empagran. ${ }^{204}$ The correct approach is to apply a modified prudential standing inquiry, which will account for all the Associated General Con-

200. As the First Circuit recently has noted,

[t]he Hartford Fire Court also held that comity considerations, such as whether relief ordered by an American court would conflict with foreign law, were properly understood not as questions of whether a United States court possessed subject matter jurisdiction, but instead as issues of whether such a court should decline to exercise jurisdiction that it already possessed.

McBee, 417 F.3d at 120 (citing Hartford Fire, 509 U.S. at 797-98 \& n.24); id. at 121 ("comity considerations are properly analyzed not as questions of whether there is subject matter jurisdiction, but as prudential questions of whether that jurisdiction should be exercised").

201. Hartford Fire, 509 U.S. at 799 ("We have no need in this litigation to address other considerations that might inform a decision to refrain from the exercise of jurisdiction on grounds of international comity.").

202. Empagran II, 417 F.3d 1267, 1271 (D.C. Cir. 2005).

203. See McCready, 457 U.S. at 477-78 (noting the indefiniteness of the proximate cause inquiry). See generally Palsgraf v. Long Island R.R., 162 N.E. 99, 99-101 (N.Y. 1928); id. at 101 (Andrews, J., dissenting).

204. See 2 WALlER, supra note $19, \S 13.23$ (noting that questions remain open after Empagran and the exception is being tested in a wave of new litigation). 
tractors factors-including the proximate cause question imbedded in those factors-and permit consideration of concerns for comity and deterrence. ${ }^{205}$

\section{A. The Indeterminacy of Proximate Cause}

On remand in Empagran II, the lower court defined the Empagran exception as a proximate cause analysis. ${ }^{206}$ It noted the language of the FTAIA required that an effect on U.S. commerce "give rise to" a claim. That language "indicates a direct causal relationship, that is, proximate causation, and is not satisfied by the mere but-for 'nexus' the appellants advanced." 207 Initially, why "gives rise to" equates to proximate cause is not clear. The court cited no authority for that proposition, which the plaintiffs had conceded.208

The Empagran II court's proximate cause analysis would be difficult to replicate reliably. Applying that standard, the court held the plaintiffs' world-wide conspiracy argument, supported by the co-conspirators' arbitrage concerns, "demonstrates at most but-for causation."209 The causal connection apparently was not proximate because two sets of fixed prices were involved-the fixed prices in domestic U.S. commerce that facilitated price-fixing in foreign commerce, and the fixed prices in foreign commerce that actually, directly, caused the plaintiffs' injury. ${ }^{210}$ But the distinction is not so neat as the D.C. Circuit believed. The distinction relies on a set of interdependent, but separable, geographic markets. It is not supportable if purchasers actually treat regional markets as interchangeable. Apart from saying so, it is not clear what about the worldwide price-fixing scheme in Empagran led to an indirect and merely but-

205. See Associated Gen. Contractors of Cal., Inc. v. Cal. State Council of Carpenters, 459 U.S. 514, 532, 537-40 (1983) (considering proximate cause as an element of the standing inquiry).

206. Empagran II, 417 F.3d at 1271 ("The statutory language-'gives rise to'-indicates a direct causal relationship, that is, proximate causation, and is not satisfied by the mere but-for 'nexus' the appellants advanced in their brief.")

In OSRecovery, Inc. v. One Groupe International, Inc., 354 F. Supp. 2d 357 (S.D.N.Y. 2005), the district court considered a complaint seeking to apply the RICO statute extraterritorially. Despite the absence from the RICO scheme of a statute like the FTAIA, the court relied on the effects test from the antitrust scheme to hold that the U.S. effect of conduct must "directly cause[ ]" a foreign plaintiff's loss for the law to apply extraterritorially. Id. at 367.

207. Empagran II, 417 F.3d at 1271.

208. Id. at 1270-71 ("the statutory language-'gives rise to'-indicates a direct causal relationship, that is, proximate causation"); id. at 1270 (plaintiffs' concession). In fact, the FTAIA contains a textual clue that "gives rise to" does not imply the kind of directness requirement the D.C. Circuit, since followed by a handful of district courts, saw fit to impose. The first element of the FTAIA analysis requires a demonstration that conduct have a "direct, substantial, and reasonably foreseeable effect" on domestic commerce, import commerce, or certain types of export commerce. 15 U.S.C. § 6(a)(1) (2000). See supra notes 76-91 and accompanying text (analysis of the FTAIA). But the second element requires only that the effect "gives rise to a claim" under the antitrust laws. 15 U.S.C. $\S 6(\mathrm{a})(2)$. The statute lacks any requirement of a direct relationship between the effect and the plaintiff's claim.

209. Empagran II, 417 F.3d at 1271.

210. Id. 
for, rather than a direct and proximate, causal nexus. ${ }^{211}$

The only other federal court of appeals to interpret Empagran, the Eighth Circuit in In re Monosodium Glutamate Antitrust Litigation, followed the Empagran II court's lead. ${ }^{212}$ It affirmed the lower court's holding that allegations of a worldwide conspiracy are not sufficient to make out the Empagran exception. ${ }^{213}$ Like the D.C. Circuit in Empagran II, the Eighth Circuit's opinion in In re $M S G$ reads like an application of a per se rule of nonextraterritoriality. It merely held allegations of a worldwide conspiracy did not rise to the lead of allegations of a proximate causal connection to a domestic effect. ${ }^{214}$ The court gave no indication that some form of allegation might suffice to make out the Empagran exception.

Other courts have engaged in similarly indeterminate analyses of proximate versus but-for causation. A magistrate judge in the Southern District of New York, in Latino Quimica-Amtex S.A. v. Akzo Nobel Chemicals B.V., held that plaintiffs' claims did not meet the Empagran exception. ${ }^{215}$ In that case, plaintiffs' counsel conceded the application of the proximate causation rule. ${ }^{216}$ Interestingly, the court-citing Associated General Contractors and Blue Shield of Va. v. McCready-grounded its proximate cause standard in "antitrust principles requiring that an antitrust injury-in-fact be caused directly by a defendant's conduct"217_ thus, antitrust standing principles. The Latino-Quimica-Amtex court denied plaintiffs leave to amend their complaint to include allegations, supported by an economic expert, of a worldwide ripple effect of price-fixing in U.S. commerce. ${ }^{218}$ Like Empagran II, it did what the Supreme Court

211. A second problem with the Empagran II court's analysis is that it fails to apply the comity and deterrence principles that underlie the Supreme Court's analysis of the FTAIA. The Supreme Court denied certiorari. Empagran S.A. v. F. Hoffman-LaRoche, Ltd., 126 S. Ct. 1043 (2006).

212. In re Monosodium Glutamate Antitrust Litig., Nos. 05-4303 and 05-4307, slip op. 6, 7 (8th Cir. Feb. 8, 2007).

213. Id. at 8 .

214. Id. at 7-8.

215. Latino Quimica-Amtex S.A.V. Akzo Nibel Chems. B.V., No. 03 Civ. 10312 (HBDF), 2005 WL 2207017 (S.D.N.Y. Sept. 8, 2005). Plaintiffs had alleged that "unlawful price fixing and market allocation conduct had adverse effects in the United States and in other nations that caused injury to Plaintiffs in connection with their foreign MCAA purchases." Id. at *9. Other allegations stated that "'Defendants['] and their co-conspirators' illegal contract, combination and conspiracy to harm U.S. and world commerce directly injured Plaintiffs." Id. (quoting the complaint). See also In re Dynamic Random Access Memory (DRAM) Antitrust Litig., No. C02-1486 PJH, 2006 WL 515629, at *4 (N.D. Cal. March 1, 2006) (holding that allegations of a worldwide conspiracy "[w]ithout more . . . constitute no more than the 'but-for' causation that the Empagran cases find objectionable").

216. Latino Quimica-Amtex, 2005 WL 2207017, at *8.

217. Id. (citing Blue Shield of Va. v. McCready, 457 U.S. 465, 477 (1982), and Associated Gen. Contractors of Cal., Inc. v. Cal. State Council of Carpenters, 459 U.S. 519, 532-34 (1983)).

218. Id. at *13. The magistrate judge held plaintiffs' alleged "causal link . . . [was] simply too indirect to support" a finding of subject matter jurisdiction. Id. at *12-*13 (citing Empagran II, 417 F.3d 1267 (D.C. Cir. 2005); MM Global Servs., Inc. v. Dow Chem. Co., 
in Empagran had refused to do, and held foreign harm was per se not cognizable in a U.S. court.

One case dismissing for failure to meet the Empagran exception shows how difficult-perhaps impossible-it will be for foreign plaintiffs to meet the proximate cause standard once a court has determined it applies. In eMag Solutions LLC v. Toda Kogyo Corp., the court dismissed claims also relying on arbitrage allegations in a worldwide conspiracy. ${ }^{219}$ "They contend that if defendants' conspiracy had not inflated U.S. prices, the foreign plaintiffs would not have been injured because lower American prices would have driven down international prices overall, including through arbitrage ...."220 The plaintiffs in eMag Solutions made an additional allegation that should have involved the interchangeability circumstance. The eMag Solutions plaintiffs specifically alleged they were prepared to engage in arbitrage to end-run fixed prices, but fixed prices in domestic U.S. commerce prevented their doing so. ${ }^{221}$

The district court nonetheless held the foreign plaintiffs had not alleged a proximate causal connection. ${ }^{222}$ It is difficult to imagine what more the eMag Solutions plaintiffs could have done to allege the U.S. effect was the proximate cause of their foreign harm. eMag Solutions may be a demonstration that the Empagran exception, if defined by proximate cause, is illusory.223 If so, Empagran would be read to have stated a per se rule of no extraterritorial application.

The District of Delaware in In re Intel Corp. Microprocessor Antitrust Litigation dismissed claims by a U.S. plaintiff claiming harm from conduct in foreign commerce. ${ }^{224}$ Like the claims rejected in Empagran II and In re MSG, the plaintiffs in In re Intel Corp. argued they were victims of a worldwide scheme with harm in foreign commerce interdependent with effects felt in domestic commerce. ${ }^{225}$ The In re Intel Corp. allegations are distinguishable from the allegations in other recent FTAIA cases of worldwide cartel activity. The unilateral conduct in In re Intel Corp. does not present the "cheating" and "arbitrage" scenarios that sup-

329 F. Supp. 2d 337 (D. Conn. 2004); In re Monosodium Glutemate Antitrust Litig., No. Civ. 00MDL1328(PAM), 2005 WL 1080790 (D. Minn. May 2, 2005)).

The Latino Quimica-Amtex court held that "nothing in these allegations even suggests that Plaintiffs' injuries were directly, or proximately, caused by the domestic effect of Defendants' alleged conspiracy." Id. at *9.

219. eMag Solutions LLC v. Toda Kogyo Corp., No. C 02-1611 PJH, 2005 WL 1712084 , at $* 4$ (N.D. Cal. Jul. 20, 2005).

220. Id. at *5.

221. Plaintiffs " "would have been particularly well-suited to replace purchases . . . in purely foreign commerce with purchases . . . in American commerce, if the conspiracy had not affected the prices . . . in American commerce." $I d$. at *4 (quoting the third-amended complaint).

222. Id. at $* 11$.

223. eMag lends support to Professor Cavanagh's conclusion that the Supreme Court in Empagran left the D.C. Circuit on remand no choice but to dismiss the plaintiffs' claims. See Cavanagh, supra note 146, at 1437.

224. 452 F. Supp. 2d 555, 556 (D. Del. 2006).

225. Id. at 559 . 
port a finding of a nexus between a U.S. effect and a foreign harm. ${ }^{226}$

In contrast those decisions, a district court in Connecticut held that allegations raising the same arbitrage concern as the worldwide conspiracy allegations in Empagran were sufficient to meet the Empagran exception.227 Plaintiffs alleged the defendants sought to "ensure that prices charged by the plaintiffs to end-users in India for products would not cause erosion to prices ... in the United States." 228 There is no apparent legally significant distinction between the allegations the District of Connecticut rejected and the allegations held elsewhere not to meet the Empagran exception. ${ }^{229}$

A district court in Minnesota initially interpreted the Empagran exception consistently with the District of Connecticut. ${ }^{230}$ Foreign plaintiffs' allegations of a worldwide conspiracy to fix the prices of fungible, globally marketed products survived a motion to dismiss. ${ }^{231}$ But demonstrating the confusion that reigns since Empagran, the Minnesota court reconsidered its holding. ${ }^{232}$ It was "persuaded by the decision and reasoning of the District of Columbia Circuit Court of Appeals" in Empagran II.233 The court held on reconsideration, in an opinion affirmed by the Eighth Circuit in In re MSG, a worldwide conspiracy allegation established at best but-for, not proximate, cause and that Empagran required the latter. ${ }^{234}$

226. See id. at 560 (relying on harm to "a rival's U.S. competitive potential from overseas injury to support the interdependedness argument).

227. MM Global Servs., Inc. v. Dow Chem. Co., 329 F. Supp. 2d 337, 338 (D. Conn. 2004).

228. Id. at 340 (quoting the amended complaint).

229. The only identifiable difference between the allegations in MM Global and the reasoning in Empagran is that the MM Global plaintiffs alleged that "[a]s a direct and proximate result" " of the defendant's conduct, harm was felt. Id. at 342 (quoting the complaint). An allegation that something was the proximate cause is an allegation of a legal conclusion, not of fact. See Latino Quimica-Amtex v. S.A.V. Akzo Nibel Chems. B.V., No. 03 Civ. 10312 (HBOF), 2005 WL 2207017, at *13 (S.D.N.Y. Sept. 8, 2005) ("[w]ithout the factual predicate to support these allegations, however, they cannot be read to plead the requisite causal link between the conspiracy's domestic effect and Plaintiffs' foreign claim"). But the proximate cause allegations in MM Global did not relate to a connection between an effect on U.S. commerce and harm in India, as most courts' understanding of the Empagran exception requires. The complaint alleged merely that the harm felt in India was " "the result of such effect on competition"" in the United States. MM Global, 329 F. Supp. 2d at 342 (quoting the complaint). But see eMag Solutions, 2005 WL 1712084, at *7 ("the district court in MM Global never discussed whether 'but-for' causation is the appropriate standard" and noting that "the case did not concern 'purely foreign' commerce").

230. In re Monosodium Glutamate Antitrust Litig. (MSG), No. Civ. 00MDL1328(PAM), 2005 WL 1080790, at *8 (D. Minn. May 2, 2005).

231. Id.

232. In re Monosodium Glutamate Antitrust Litig., No. Civ, 00MDL1328(PAM), 2005 WL 2810682, at *1 (D. Minn. Oct. 26, 2005).

233. Id. at $* 3$.

234. Id. MSG has been appealed to the Eighth Circuit. See In re Monosodium Glutamate Antitrust Litig., No. Civ. 00MDL1328(PAM), 2005 WL 2810682 (D. Minn. Oct. 26, 2005), appeal docketed, No. 03-2997 (8th Cir. Nov. 23, 2005). 


\section{B. Applying Standing Doctrine to Define the EMPAGRAN EXCEPTION}

Where the pure proximate cause standard has failed, prudential standing doctrine can answer the question. A workable definition of the scope of the Empagran exception is reached by treating it as a question of the antitrust standing doctrine, modified to encompass the considerations of comity and inverse deterrence recognized in Empagran, and developed through the common-law process. ${ }^{235}$ To be sure, the Empagran Court noted the difficulty of case-by-case analysis when it stated a bright-line rule governing suits by plaintiffs injured in wholly foreign commerce, and at least two commentators, ignoring the common-law history of antitrust adjudication, have applauded that decision. ${ }^{236}$ But the bright-line rule, and the admonition that case-by-case analysis was impractical, was justification for the Court's narrow holding per se regarding claims not connected to an effect on U.S. commerce. The Court did not purport to define how lower courts should apply the Empagran exception and certainly did not establish any per se rule governing it.

What is important about the Empagran exception is just that-it is an exception to the limitation on extraterritorial reach imposed by the FTAIA. Undefined, the exception could be limitless. Courts in theory could consider any claim of a nexus to an effect in U.S. commerce to be sufficient. ${ }^{237}$ It also could be meaningless-courts in theory could require a nexus to a domestic effect so strong that no wholly foreign harm would qualify. ${ }^{238}$ All that Empagran made clear is that the narrow bright-line rule it espoused did not define the exception. ${ }^{239}$ But the decision principles that led the Court to an understanding of the FTAIA also should, as

235. Case-by-case analysis of a range of factors is the hallmark of the Associated General Contractors analysis. See Associated Gen. Contractors of Cal. v. Cal. State Council of Carpenters, 459 U.S. 519, 531-33 (1983) (antitrust standing is a common-law analysis). See also Gregory Mktg. Corp. v. Wakefern Food Corp., 787 F.2d 92, 95 (3d Cir. 1986) (In both situations the infinite variety of claims that may arise make it virtually impossible to announce a black-letter rule that will govern in every case. Instead, previously decided cases identify factors that circumscribe and guide the exercise of judgment in deciding whether the law affords a remedy in specific circumstances.);

Bravman v. Bassett Furniture Indus., 552 F.2d 90, 99 (3d Cir. 1977) (" $\$ 4$ standing analysis is essentially a balancing test comprised of many constant and variable factors and that there is no talismanic test capable of resolving all $\S 4$ standing problems"); de Atucha v. Commodity Exch., Inc., 608 F. Supp. 510, 514 (S.D.N.Y. 1985) (interpreting the Court's standing authorities as requiring case-by-case analysis of the Associated Gen. Contractors factors).

236. See F. Hoffman-LaRoche, Ltd. v. Empagran S.A., 542 U.S. 155, 168 (2004). See also Cavanagh, supra note 146, at 1436 (calling the approach "unwise as a policy matter"); Wurmnest, supra note 3, at 220-21.

237. The holding of the District of Connecticut in MM Global, accepting a mere allegation that foreign harm was "the result of" an effect in U.S. commerce, might be thought to be an example of a nearly unlimited definition of the Empagran exception. See MM Global Servs., Inc. v. Dow Chem. Co., 329 F. Supp. 2d 337, 342 (D. Conn. 2004).

238. See, e.g., eMag Solutions, LLC v. Toda Kogyo Corp., No. C 02-1611 PJH, 2005 WL 172084, at $* 11$ (N.D. Cal. Jul. 20, 2005).

239. See Empagran, 542 U.S. at 175. 
part of a standing analysis, assist a principled understanding of the Empagran exception.

\section{Reasons for Relying on a Prudential Standing Analysis}

Prudential standing doctrine has strong arguments to recommend it. A primary accolade is that the doctrine is the most consistent with the structure of the U.S. antitrust regime. ${ }^{240}$ Although the subject matter jurisdiction question under the FTAIA remains essential to determining what conduct is cognizable in a U.S. antitrust court, the standing inquiry tells a court which plaintiff can complain about that conduct. ${ }^{241}$ Another is that the standing inquiry is malleable and subject to common-law development. It is thus an appropriate, and the only appropriate, repository of new concerns such as the comity and inverse deterrence concerns that came to the fore in Empagran. ${ }^{242}$ Those rationales cannot be fit neatly into the proximate cause inquiry followed by courts after Empagran. ${ }^{243}$ They also have no textual basis in any of the antitrust statutes.

Vis- $a$-vis subject matter jurisdiction, antitrust standing doctrine has all of the procedural advantages of permitting early dismissal of suits. ${ }^{244}$ It adds to those benefits a substantial procedural benefit of waivability (which subject-matter jurisdiction lacks). ${ }^{245}$ Early dismissal is especially important in the realm of extraterritorial antitrust enforcement because of both comity concerns and over-deterrence concerns. First, comity con-

240. Related to this structural argument is the fact that whether extraterritoriality is treated as a standing or as a subject-matter jurisdiction analysis, a private plaintiff necessarily must satisfy the standing inquiry to establish its right to sue under Clayton 4 . If courts first conduct a proximate cause inquiry to determine the reach of their subject-matter jurisdiction under the FTAIA, that same inquiry will be part of the standing analysis that will follow. See, e.g., Den Norske Stats Oljeselskap AS v. HeereMac VOF, 241 F.3d 420, 431 n.32 (5th Cir. 2001) (noting that because the FTAIA analysis was not met, the standing analysis necessarily would fail). Respecting the structure of the antitrust laws limits that redundancy.

241. See supra notes 26, 30-54 and accompanying text.

242. See McBee v. Delica Co., 417 F.3d 107, 111 (1st Cir. 2005)

(We reject the notion that a comity analysis is part of subject matter jurisdiction. Comity considerations, including potential conflicts with foreign trademark law, are properly treated as questions of whether a court should, in its discretion, decline to exercise subject matter jurisdiction that it already possesses. Our approach to each of these issues is in harmony with the analogous rules for extraterritorial application of the antitrust laws.).

243. Tellingly, neither Empagran II, nor any of the other courts analyzing the Empagran exception as a proximate cause inquiry, have even tried to analyze the comity and inverse deterrence rationales when considering the scope of the exception. See generally Empagran II, 417 F.3d 1267 (D. C. Cir. 2005).

244. See Verizon Commc'n, Inc. v. Law Offices of Curtis V. Trinko, 540 U.S. 398, 416 (2004) (Stevens, J., concurring) (noting that a court should begin by analyzing standing); Hairston v. Pac. 10 Conference, 101 F.3d 1315, 1320-21 (9th Cir. 1996) (Trott, J., concurring) (noting that standing analysis is a preliminary inquiry).

245. Compare FED. R. Civ. P. 12 (Rule 12(b)(1) arguments of a lack of subject-matter jurisdiction can be raised at any time in litigation), with NCAA v. Bd. of Regents of the Univ. of Okla., 468 U.S. 85, 97 n.14 (1984) (Court not addressing antitrust injury issue not raised by the parties). But see Reazin v. Blue Cross \& Blue Shield of Kan., Inc., 899 F.2d 951, 961 (10th Cir. 1990) ("Courts do not agree on whether antitrust standing can be waived.") (citing authorities on both sides of the question). 
cerns regularly are recognized to exist not just in the case of U.S. courts imposing actual liability in situations in which foreign sovereigns have regulatory interests, but also in the case of actors required to submit to U.S. regulatory procedures, including judicial proceedings, where foreign sovereign regulation is implicated. ${ }^{446}$ Second, over-deterrence concerns-and the inverse-deterrence concerns that exist at the extremeincrease the further the litigation is permitted to proceed before the resolution of a dispositive motion. The very expense of defending against massive antitrust litigation usually causes defendants to seek settlement regardless of the merits of the claims, and sometimes with little regard to the likelihood of the plaintiffs' success in trial. ${ }^{247}$

Waivability helps to realize the goal of optimization. Waiver of a ground for dismissal is a recognition that the benefits to the defendant and to the court system of dismissal decrease the longer a defendant in litigation waits to seek it. ${ }^{248}$ The waiver doctrine also recognizes that at some point, the investment in litigation by the plaintiffs and by the court system has reached a level that warrants respect. When the harm to the plaintiff from dismissing the case on procedural grounds exceeds the benefit to the defendant from its dismissal, it makes sense to refuse dismissal on grounds of waiver. Under a prudential standing analysis, a court retains this flexibility.

\section{Updating Antitrust Standing}

The prudential standing inquiry developed under interpretations of Clayton 4 does not appropriately capture the costs and benefits of private extraterritorial enforcement, which now are understood to include (1) international comity ramifications of extraterritorial enforcement, and (2) harm to the public enforcement regime under the inverse deterrence rationale. Those must be included in a modern analysis of which plaintiff is best situated to sue. ${ }^{249}$ Doing so will enable tailoring of antitrust remedies to serve the essential deterrence and compensation goals of

246. A common example of bare judicial proceedings alone giving rise to comity concerns is the Foreign Sovereign Immunities Act ("FSIA") context. 28 U.S.C. $\S \S 1602-1608$ (2000 \& Supp. 2004). Courts repeatedly have held that immunity under the FSIA is immunity from suit, not just from liability. Although the analyses under the FSIA and FTAIA are not related, as a matter of the first principles comity question the FSIA analysis is instructive. $C f$. United States v. LSL Biotech, 379 F.3d 672, 680 (9th Cir. 2004) (reliance on definitions of "directness" under the FSIA to inform its meaning in the FTAIA).

247. See Frank H. Easterbrook, Discovery as Abuse, 69 B.U. L. Rev. 635, 636-38 (1989); Stancil, supra note 39, at 996-1000.

248. For example, if the comity or over-deterrence concern implicates the very fact of a defendant's being required to submit to discovery, once discovery has been completed or substantially completed, that harm has been fully wrought. The benefit of dismissal at that stage no longer includes the benefits of avoiding expensive and burdensome discovery and of avoiding being required unfairly to submit to the U.S. antitrust regulatory scheme.

249. The ability of standing analysis to accommodate changing realities is one of its great strengths. See, e.g., McBee v. Delica Co., 417 F.3d 107, 110-11 (1st Cir. 2005) (relying on antitrust extraterritoriality decisions because they reflect consideration of circumstances not considered in earlier Lanham Act decisions). 
antitrust. 250

\section{a. New Emphasis on Comity Concerns}

The Empagran Court admonished that litigation must not go forward if foreign comity concerns militated sufficiently strongly against it. ${ }^{251}$ The rule following Empagran is that some safeguard must be in place. As in the domestic enforcement sphere, with regard to extraterritorial enforcement, courts cannot rely on private plaintiffs to self-select and not bring suit because of diplomatic concerns. ${ }^{252}$ A modified prudential standing analysis permits courts to decline to hear cases that, based on their developed common-law experience, should not be cognizable. This flexible analysis of comity concerns can take account of changing circumstances horizontally-with regard to which foreign sovereign is in question, and vertically-over time.

The Empagran litigation is a prime example of the benefits of malleability in the invocation of foreign comity concerns. Consider first horizontal variation. At issue in Empagran were foreign sovereigns with which the United States has diplomatic ties. The comity analysis for other foreign sovereigns might differ. ${ }^{253}$

The degree to which comity concerns are implicated by extraterritorial enforcement also depends on the nature of that sovereign's economic regulation. Empagran raised comity concerns with regard to four foreign sovereigns-Australia, Ecuador, Panama, and the Ukraine-whose antitrust regulation, or lack of regulation, was threatened with preemption if the foreign plaintiffs' claims were permitted to go forward in U.S. court under U.S. law. ${ }^{254}$ Scholars analyzing Empagran have ignored the fact that those countries did not appear in the litigation raising comity concerns. $^{255}$ The concerns came, instead, from others such as Britain, Canada, Germany, and Japan-major U.S. trading partners with robust antitrust regulation. ${ }^{256}$ The U.S. government, the parties, and other amici also advanced comity arguments, primarily in the contexts of U.S. allies with sophisticated antitrust laws. ${ }^{257}$ Neither scholarly nor judicial analy-

250. Cf. Page, supra note 22, at 1450-52 (arguing that standing optimizes remedies in the domestic enforcement context).

251. F. Hoffman-LaRoche, Ltd. v. Empagran S.A., 542 U.S. 155, 173-75 (2004).

252. See supra notes 66-68 and accompanying text (noting private plaintiffs' incentives to sue in U.S. courts).

253. Cf. Pfizer, Inc. v. Gov't of India, 434 U.S. 308, 319-20 (1978) ("It has long been established ... that it is within the exclusive power of the Executive Branch to determine which nations are entitled to sue.").

254. See Empagran, 542 U.S. at 159.

255. See Wurmnest, supra note 3, at 216 (countries with weak antitrust systems have not complained openly about U.S. extraterritorial regulation).

256. See supra note 6 and accompanying text (describing amicus involvement of Canada, Germany, Belgium, the United Kingdom, Northern Ireland, the Netherlands, and Japan); Wurmnest, supra note 3, at 216 ("regulatory conflicts primarily concern industrialized countries that have robust antitrust laws").

257. But see Cert.-Stage Brief of the Chamber of Commerce of the United States as Amicus Curiae Supporting Petitioners at 15-7, Empagran, 542 U.S. 155 (2004) (No. 03-724) (making arguments in the specific context of Australia). 
sis has considered the extent to which the comity concerns that were advanced were relevant to the particular sovereign nations whose antitrust regulation-or lack thereof, in the case of Ecuador ${ }^{258}$ - supposedly were threatened with being undermined. 259

In Hartford Fire, the Court observed that some types of extraterritorial jurisdiction of U.S. economic regulation do not undermine foreign sovereigns' efforts to regulate their own domestic commerce. 260 The Court asked only whether U.S. regulation actually conflicted with regulation by foreign sovereigns. Because it did not, extraterritorial jurisdiction was found. $^{261}$ There may be a good explanation why foreign amici in $\mathrm{Em}$ pagran were limited to those nations with sophisticated antitrust regulation. Sovereign nations without such regulation-but suffering perhaps substantial harm from cartel conduct in their economies ${ }^{262}$ - may be illinclined to oppose assistance by U.S. courts in maintaining competitive conditions in their own domestic commerce. ${ }^{263}$ At a minimum, a court should explore this question in an individual case before assuming the Empagran approach applies to a particular foreign sovereign. ${ }^{264}$

258. Ecuador does not have an antitrust enforcement regime. See Bruce M. Owen, Competition Policy in Latin America 63 (Stanford Law Sch., John M. Olin Program in Law \& Econ., Working Paper No. 268, 2003) (table listing Latin American competition policies and enforcement agencies).

259. Cf. Podgor, supra note 2, at 29 ("Issues of comity are not concerns when another country seeks the assistance of the United States. The strong prosecutorial abilities and the resources available for prosecution may motivate another country to seek the aid of the United States in curtailing improprieties occurring within their country.").

260. Hartford Fire Ins. Co. v. California, 509 U.S. 764, 798-99 (1993).

261. Id. at 799.

262. See Levenstein \& Suslow, supra note 3, at 812-18 (calculating that in 1997 , developing countries imported approximately $\$ 50$ billion in goods in channels of trade affected by cartels - a larger amount as a proportion of total imports and GDP than developed countries imported); Joseph Francois \& Henrik Horn, Antitrust in Open Economies, IIIS Discussion Paper No. 120, at 15 n.11 (2006) (noting that "a domestic cartel . . . is unambiguously bad for overall national welfare").

263. See Podgor, supra note 2, at 29 (noting "situations when another country welcomes the United States into their jurisdiction for the purpose of proceeding with [a] prosecution." "This form of cooperative assistance needs to be fostered"). Cf. Levenstein \& Suslow, supra note 3, at 845-46 (discussing the possibility that courts in countries with more sophisticated antitrust regimes might provide remedies to foreign plaintiffs injured by cartels but lacking an antitrust remedy in their home country) (citing Provimi, Ltd. v. Avenits Animal Nutrition S.A., [2003] EWHC (QB) 1211 (Eng.) (permitting suit by non-English citizens over the same vitamins cartel at issue in Empagran)); Francois \& Horn, supra note 262 , at 15,20 (discussing the possibility of extraterritorial application of competition policy). This analysis ignores the question whether remedying foreign social harm is an appropriate use of this country's judicial resources. See Podgor, supra note 1, at 101-02 ("cost concerns are equally important"); id. at 92 (citing United States v. Pasquantino, 544 U.S. $349,371-72$ (2005), for the proposition that U.S. prosecutorial resources might be better devoted elsewhere).

264. The foreign sovereigns at issue in Empagran have not demonstrated an aversion to extraterritorial jurisdiction, apart from Australia, which has taken active efforts to oppose U.S. antitrust courts' extraterritorial jurisdiction. See, e.g., 1 WALLER, supra note $84, \S 4.17$ (noting Australia's "blocking statute"). Ecuador does not have an antitrust scheme at all. See supra note 247. But see Francois \& Horn, supra note 262, at 15 n.11 (noting that "the net importer government may also support a domestic cartel"); Levenstein \& Suslow, supra note 3, at 819-20 (noting that "[1] ocal price wars can benefit consumers," creating a "possibility ... [of] short-term benefits for developing country consumers, if their markets 
The "vertical" (temporal) analysis of comity considerations is not constant either. For any one foreign sovereign, U.S. diplomatic policy toward that country is not unchanging. Legal rules developed based on the comity analysis on day zero might not be relevant on day one. ${ }^{265}$ The same applies with regard to changing economic regulations worldwide. The advent of antitrust regulations in foreign countries in recent decades has been a much remarked phenomenon. ${ }^{266}$ Justification for extraterritorial application of U.S. antitrust laws will decrease as that development continues and other sovereigns' regulations become more sophisticated. Conversely, should there be a slowing or setback in that development, the need for extraterritorial enforcement of U.S. antitrust laws might increase. Few issues demand the flexibility of common law analysis so much as does the comity question. ${ }^{267}$

\section{b. New Understanding of the Inverse Deterrence Rationale}

The inverse deterrence rationale had not been part of the extraterritoriality analysis before Empagran. In Empagran, not only was the U.S. Department of Justice's leniency policy discussed, foreign governments as amici advanced their own amnesty policies as giving rise to inverse deterrence concerns. ${ }^{268}$ The Supreme Court gave substantial deference to

are used to discipline transgressors" from the agreed cartel price and output). Perhaps for those reasons, Professor Podgor has argued that foreign governments should be expected to specifically request an assertion of jurisdiction over a harm felt within their sovereign borders. See Podgor, supra note 1 , at 102.

265. A sufficient example of such temporal change is Iran. Iran was a plaintiff in Pfizer Corp. v. Government of India, 434 U.S. 308 (1978), and was held in 1978 to be a "person" permitted to sue under the antitrust laws. See id. at 309, 318. Today, Iran is a part of what the Bush administration has declared the "axis of evil" and is a designated state sponsor of terror. See Address Before a Joint Session of the Congress on the State of the Union, 1 Pub. PAPers 129, 131 (Jan. 29, 2002), available at http://www.whitehouse.gov/news/releases/2002/01/20020129-11.html ("States like . . . [Iran, Iraq and North Korea] . . constitute an axis of evil . ..."). For Iran's status as a state sponsor of terrorism, see U.S. Dep't of State, State Sponsors of Terrorism (Table), available at http://www.state.gov/s/ct/c14151 .htm. The Court in Pfizer noted that it remains "within the exclusive power of the Executive Branch to determine which nations are entitled to sue." Pfizer Corp., 434 U.S. at 320; see also id. at $310 \mathrm{n} .1$ (referencing nations, including Vietnam, whose suits were not permitted because the governments were not recognized by the U.S. government).

266. See William E. Kovacic, Lessons of Competition Policy Reform in Transition Economies for U.S. Antitrust Policy, 74 ST. JoHN's L. Rev. 361, 361-63 (2000); Delrahim, supra note 5, at 2 ("there are nearly 100 jurisdictions with antitrust laws of one sort or another, from Albania to Zambia").

267. But see Wickard v. Filburn, 317 U.S. 111, 129 (1942) (describing legislation as "more flexible and responsible" than common-law analysis). Professor Hovenkamp argues that because of stare decisis principles, common-law adjudication can produce inflexible results if courts impose per se rules with insufficient underlying common-law percolation. See Hovenkamp, supra note 3, at 118. See also William E. Kovacic, Antitrust in the O'Connor-Rehnquist Era: A View from Inside the Supreme Court, 20 AnTitrust 21, 23-24 (2006) (citing to papers of Justices Blackmun, Powell, and Marshall to demonstrate the difficulties of overturning the per se rule once it has been applied). Those arguments do not undermine the assertion in the text. This article advocates an approach to extraterritoriality that minimizes the development of per se rules.

268. See F. Hoffman-La Roche Ltd. v. Empagran S.A., 542 U.S. 155, 168 (2004); Brief for the Federal Republic of Germany et al. as Amicus Curiae, Supporting Petitioner at 28, Empagran, 542 U.S. 155 (2004) (No. 03-724). Foreign sovereigns increasingly are using 
those arguments.

Like the comity concerns discussed above, the inverse deterrence rationale is not static. Analysis of the inverse deterrence concern depends on, at a minimum, changing Executive Branch enforcement policy. The Department of Justice's amnesty program is a matter of prosecutorial discretion, not statute or even administrative regulation. It can be alteredlimited or expanded-through mere executive fiat. ${ }^{269}$

Other external effects of the rationale are the prevalence, or lack thereof, of major cartel behavior. Cartelization has not been a consistent phenomenon historically. ${ }^{270}$ Notably, scholarship demonstrates that 1982, the year of the FTAIA's enactment, was during a nearly half-century lull in the prevalence of multinational cartels. ${ }^{271}$ The specific issues of worldwide interdependence that the Empagran litigation has raised were not well understood at the time the FTAIA was enacted, and international cartel activity was not a significant driver of the legislation.

\section{c. Optimal Extraterritorial Enforcement}

If, as Professor Page has argued, optimization is accomplished through a standing rationale, ${ }^{272}$ in the extraterritorial arena, the optimization goals are best accomplished through a standing rationale extended into the extraterritorial enforcement sphere. ${ }^{273}$ The modified prudential standing analysis will permit antitrust courts efficiently to implement the policies recognized in Empagran in a manner to avoid over-deterrence and under-deterrence (comprised in part of inverse deterrence) concerns. Of course, the deterrence questions incorporate the principle of comity: regulation that violates comity principles necessarily involves over-deterrence (stepping on toes or overlapping regulation) or under-deterrence (failing to deter when a foreign sovereign seeks assistance from the U.S. enforcement scheme).

Optimal enforcement, whether in the domestic or extraterritorial arena, depends on value judgments as to the goal of the regulatory

leniency or amnesty programs as part of a "carrot and stick" approach to anti-cartel enforcement. See Scott D. Hammond, Deputy Assistant Attorney Gen., Charting New Waters in International Cartel Prosecutions, 20th Annual Nat'l Inst. on White-Collar Crime 2 (March 2, 2006), available at http://www.usdoj.gov/atr/public/speeches/214861.pdf. See also Levenstein \& Suslow, supra note 3, at 805 (describing the development of foreign amnesty programs).

269. Cf. Max Huffman, Broken Trusts: The Texas Attorney General Versus the Oil Industry, 1889-1909, 15 W. Legal Hist. 215 (2002) (book review) (discussing changing executive enforcement policy); HyLton, supra note 65, at 48 (describing executive enforcement decisions as purely discretionary); Podgor, supra note 2, at 24-25 (describing the extent of prosecutorial discretion and the discretionary nature of internal Justice Department guidelines).

270. Connor, supra note 163, at 1-2 (describing ebbs and flows in cartel activity).

271. Id. at 1 (describing the "inter-war period").

272. See Page, supra note 22, at 1483-85.

273. Cf. supra note 250 and accompanying text. 
scheme. ${ }^{274}$ The optimal level of enforcement minimizes the deviation from that goal. In the domestic arena, general modern agreement exists that the goal is maximization of social wealth through the protection of competition. ${ }^{275}$ Optimal enforcement domestically will minimize deviation from that goal. 276

The value judgment for extraterritorial enforcement requires an answer to the questions, "whose wealth should be maximized, through the protection of what competition?" Empagran recently has echoed the rule that the U.S. antitrust laws exist to protect domestic U.S. commerce. ${ }^{277}$ Optimal extraterritorial enforcement will minimize deviation from that goal. Thus, conduct that is harmful to domestic U.S. commerce should be compensated for and deterred; and conduct that is beneficial to domestic U.S. commerce should be permitted to continue-even at the potential expense of permitting harm in foreign commerce to go unremedied. ${ }^{278}$

\section{i. Extraterritorial Over-deterrence Concerns}

Over-deterrence concerns also arise in the context of private extraterritorial enforcement. Concern for liability far disproportionate to the effect of conduct on U.S. commerce risks deterring potential antitrust defendants from engaging in conduct that is economically beneficial domestically. The concern for over-deterrence due to excessive liability has three manifestations in the context of extraterritoriality. One is an extension of the notion of a false positive. The concerns for false positives become more compelling when the liability that may be imposed is based on claims by a world-wide plaintiff class.

A related concern is that of overlapping regulation. A defendant subject to treble damages liability in a U.S. antitrust court for foreign harm might also be subject to liability in the courts of a foreign sovereign for that same harm. ${ }^{279}$ This especially might occur if overreaching by U.S.

274. See Eleanor M. Fox, The Modernization of Antitrust: A New EquilibRium (1981), reprinted in The Political Economy of the Sherman Act 259, 261 (E. Thomas Sullivan ed., 1991) ("The isolation of efficiency as the sole goal of antitrust requires a conscious rejection of equally dominant values that underlie the antitrust statutes.").

275. See Bork, supra note 74, at ix-xiv; Hovenkamp, supra note 3, at 1; Hylton, supra note 65, at 43-44; Posner, supra note 74, at 2.

276. This is even at the potential expense of undermining other policy goals with which antitrust law is not concerned. $C f$. Stancil, supra note 39, at 965 (over-deterrence argument made with reference to the favored "consumer welfare" standard).

277. See supra text following note 146 (arguing Empagran is a definitive modern statement that the goals of the antitrust laws are to protect U.S. commerce).

278. See F. Hoffman-La Roche, Ltd v. Empagran S.A., 542 U.S. 155, 165 (2004) ("the justification for that interference" with the foreign nation's regulatory authority "seems insubstantial"); Matsushito Elec. Indus. Co. v. Zenith Radio Corp., 486 U.S. 586 (1986) (no basis to protect against harms offered in Japan when conduct did not harm U.S. consumers).

279. See Epstein \& Greve, supra note 74, at 22 (noting concerns for an "n-front war in countless and often hostile jurisdictions"); Francois \& Horn, supra note 262, at 20 ("Exporting firms in Country 1 would then come under two jurisdictions, and it would here seem rational that the more stringent of the two applied.") (failing to account for the power of private plaintiffs to sue regardless of overlapping foreign jurisdiction); Wolfgang 
plaintiffs and courts encourages retaliatory exercises in extraterritorial regulation by foreign sovereigns. ${ }^{280}$

The third manifestation of the over-deterrence concern in the extraterritoriality context is that conduct that harms competition in a foreign market might be beneficial, or neutral, to competition in domestic commerce. Permitting suit by a plaintiff injured in foreign commerce does nothing to remedy harm suffered in U.S. commerce, but it chills conduct that is desirable in U.S. commerce. An example of this third manifestation of over-deterrence would be a course of price-fixing conduct in a foreign market used to fund pro-consumer price-cutting in U.S. commerce. In Matsushita Electric Industrial Co. v. Zenith Radio Corp. ${ }^{281}$ plaintiffs argued that price fixing by defendants in the Japanese market was used to fund below-cost pricing in U.S. markets. Under that scheme, regulators and consumers in Japan might be concerned about the alleged price-fixing conduct in that location, but U.S. consumers gained from the alleged antitrust violations. Courts in the United States should not be concerned about harm overseas that is pro-competitive domestically. ${ }^{282}$

In the specific context of export commerce, the FTAIA expressly implements the policy of avoiding over-deterrence. Under section $6 \mathrm{a}(1)(\mathrm{B})$, an "effect" that can give rise to antitrust liability in export commerce must be an effect on the business of U.S. exporters. ${ }^{283}$ An effect on export commerce that harms foreign purchasers is explicitly excluded. ${ }^{284}$

\section{ii. Extraterritorial Under-deterrence Concerns}

The opposite concern, and one that motivates plaintiff-friendly decisions in the extraterritoriality analysis, is that of under-deterrence. ${ }^{285}$ The

Kerber \& Oliver Budzinski, Competition of Competition Laws: Mission Impossible?, in Competition Laws in Conflict: Antitrust Jurisdiction in a Global Economy 31, 45 (Richard A. Epstein \& Michael S. Greve eds., 2004) ("the [effects] doctrine has the potential to generate jurisdictional conflicts among the many countries where a given merger or cartel practice may have an effect"); Podgor, supra note 2, at 23 (noting that an effects-based test "has few, if any, limits" and that "[t]his is particularly true as society becomes more globalized"); Wurmnest, supra note 3, at 210-12 (describing the phenomenon of overlapping regulation and the inability of bilateral agreements to affect private antitrust litigation). Cf. HovenKAMP, supra note 3 , at 76 (noting the concern for duplication of damages when a defendant is subject to overlapping federal and state regulation).

280. See Podgor, supra note 2, at 23 ("Opening the door to more extraterritorial prosecutions may influence other countries to proceed in a similar fashion."). Retaliation is a result of under-emphasis on the comity concern.

281. Matsushita Elec. Indus. Co. v. Zenith Radio Corp., 475 U.S. 574, 574 (1986).

282. Cf. Easterbrook, supra note 199, at 708-09 (arguing that predation is not a concern unless the predator can recoup its losses incurred in predation).

283. 15 U.S.C. $\$ 6 \mathrm{a}(1)$ (B) (2000) ("conduct has a direct, substantial and reasonably foreseeable effect . . . on export commerce with foreign nations of a person engaged in export commerce in the United States"). See 1 WALlER, supra note 84, § 9.7 (describing the FTAIA's coverage of exporters).

284. One might argue under the expressio unius canon that this narrow concern for U.S. exporters proves a broader concern for foreign harm outside the context of export commerce. However, no such argument has been made or accepted.

285. See Pfizer Corp. v. Gov't of India, 434 U.S. 308, 315 (1978). Cf. McBee v. Delica Co., 417 F.3d 107, 119 (1st Cir. 2005) ("In both the antitrust and the Lanham Act areas, there is a risk that absent a certain degree of extraterritorial enforcement, violators will 
under-deterrence concern has two manifestations-the traditional concern for liability that is insufficient to deter harmful conduct, and the recently-recognized inverse deterrence concern.

The traditional manifestation, which the Supreme Court recognized in Pfizer Corp. v. Government of India, ${ }^{286}$ is that regulatory gaps decrease the downside risk of liability for global cartels. ${ }^{287}$ "[P] ersons doing business both in this country and abroad might be tempted to enter into anticompetitive conspiracies affecting American consumers in the expectation that the illegal profits they could safely extort abroad would offset any liability to plaintiffs at home." 288 The degree to which this concern is appropriate in the modern day is subject to debate. A much remarked phenomenon since Pfizer Corp. was decided in 1978 is the development of antitrust agencies worldwide. ${ }^{289}$ A recent paper by an antitrust division official notes that "[a]ntitrust authorities throughout the world have become increasingly aggressive in investigating and sanctioning cartels." 290 The result of that change may be that material regulatory gaps are limited. 291

Also, strong questions exist whether a U.S. antitrust court should be concerned if the remedy under U.S. law fails sufficiently to deter an-

either take advantage of international coordination problems or hide in countries without efficacious antitrust or trademark laws, thereby avoiding legal authority.").

286. 434 U.S. 308.

287. See id. at 315; see also Buxbaum, supra note 6, at 1096-97 (noting arguments that "aggregate global sanctions against hard-core cartels are insufficient to deter price-fixing"); Levenstein \& Suslow, supra note 3, at 801; Wurmnest, supra note 3, at 224 (characterizing global markets as a "loophole" and citing both the problems of jurisdictional gaps and difficulties for plaintiffs in being required to litigate in multifarious jurisdictions).

288. Pfizer, 434 U.S. at 313. See Wurmnest, supra note 3, at 205 ("International conspiracies profit enormously from these enforcement gaps.") (citing Julian Clarke \& Simon J. Evenett, The Deterrent Effect of National Anticartel Laws: Evidence from the International Vitamins Cartel, 47 AnTitrust Bull. 689, 689-726 (2003)). Two commentators recently noted the possibility that the under-deterrence phenomenon observed in Pfizer Corp. might itself have foreign comity impact. "The reach of the U.S. antitrust laws may be arbitrary in the sense that it could treat very differently activities that are economically indistinguishable from the point of view of developing countries." Levenstein \& Suslow, supra note 3, at 848. See also Antitrust Modernization Comm., supra note 179, at 6 (noting the comity implications of denying suit to foreign plaintiffs).

289. See Kovacic, supra note 266, at 361-63; Delrahim, supra note 5, at 2. Although some have argued "anti-cartel enforcement is too difficult for agencies that are relatively new to antitrust enforcement," others maintain that view is inaccurate, and that anti-cartel enforcement should be the primary focus of new regulatory regimes. Barnett, supra note 79, at 4. See also id. at 4-5 (arguing for international coordinated efforts in criminal enforcement); Epstein \& Greve, supra note 74, at 1 (noting "multiple (and proliferating) antitrust authorities"). But see Wurmnest, supra note 3, at 216 (noting the ineffectiveness of antitrust enforcement in developing countries).

290. Hammond, supra note 268 , at 2 ; see also Barnett, supra note 79 , at 4 . But see Levenstein \& Suslow, supra note 3, at 851 (noting that "antitrust institutions either do not exist in most developing countries or do not have the wherewithal to address this problem").

291. Cf. Paul Stephan, Against International Cooperation, in Competition Laws in Conflict: Antitrust Jurisdiction in a Global Economy 66, 76 (Richard A. Epstein \& Michael S. Greve, eds. 2004) (noting attention to the possibility of "soft harmonization" of antitrust laws, defined as establishing baseline levels of antitrust regulation to which sovereigns may aspire). 
ticompetitive conduct in wholly foreign commerce. So long as the deterrence and compensation functions are served in domestic commerce, that a cartel realizes profits in the aggregate is a problem for foreign sovereigns. It is not impossible that such a laissez-faire attitude toward unregulated foreign markets will result in sophisticated cartels directing their conduct only at the regulatory gaps-perhaps even, as alleged in Matsushita, with the effect of funding vigorous competition in U.S. markets.

The second under-deterrence manifestation is the particular concern recognized in Empagran. A negative externality of broad private enforcement is, paradoxically, decreased future cartel enforcement. ${ }^{292}$ The massive civil liability to private plaintiffs risks overbearing the benefits available to a would-be informant from the Department of Justice's amnesty program. They are unlikely to disclose participation, which-in a manner akin to a "mutually assured destruction" principle, has the effect of cementing cartels. Because inverse deterrence arises at the extreme of over-deterrence, like the over-deterrence concerns addressed above, the inverse deterrence concern becomes all the more relevant when litigation increases in size-such as a case involving worldwide plaintiff classes.

\section{Applying the Updated Standing Analysis to the Empagran Exception}

The updated standing analysis requires courts to consider the following: (1) the question of antitrust injury; (2) the indirect purchaser question from Illinois Brick; and (3) the remaining factors of the availability of other plaintiffs, the concerns for judicial manageability, and concerns for the risk of duplicative recoveries or complex apportionment of damages $^{293}$ - as well as (a) comity and (b) inverse-deterrence concerns. Those latter concerns are best considered part of what this article has called "a vaguely defined amalgam of other considerations" that make up the third facet of the standing inquiry.

Courts deciding whether claims of foreign harm can be brought in U.S. antitrust courts post-Empagran can apply the modified Associated General Contractors framework to the extraterritoriality problem. Application of the Associated General Contractors factors in the extraterritoriality arena was undertaken two decades ago in de Atucha $v$. Commodity Exchange, Inc. ${ }^{294}$ In that case, an Argentinean plaintiff who purchased silver on the London Metals Exchange sought to sue in a U.S. antitrust court. ${ }^{295}$ The plaintiff alleged harm resulting from the infamous effort by the Hunt brothers to monopolize the silver market. ${ }^{296}$ The court noted both that the injury suffered was causally remote from effects in U.S. commerce, and that domestic plaintiffs were available to vindicate

292. See Levenstein \& Suslow, supra note 3, at 848-49 (noting the problem the threat of civil suit presents to the operation of amnesty programs, and a unique problem associated with a requirement that the EC reveal the identity of firms receiving amnesty).

293. See supra notes 34-40 and accompanying text.

294. de Atucha v. Commodity Exch., Inc., 608 F. Supp. 510, 514-18 (S.D.N.Y. 1985).

295. Id. at 513 .

296. Id. 
the deterrence concern. ${ }^{297}$ The court denied standing. ${ }^{298}$ de Atucha did not have before it the injunction from Empagran that it consider comity and inverse-deterrence concerns. Other courts considering prudential standing arguments have tended to limit their analysis to the question of antitrust injury - the first, and perhaps foremost, of the Associated General Contractors elements, but not the entire question. ${ }^{299}$

\section{a. Antitrust Injury in Extraterritorial Application}

In extraterritorial application, the antitrust injury question is whether the U.S. antitrust laws exist to remedy the particular foreign harm. This question has two parts. The first-whether the harm, assuming it was suffered in U.S. commerce, is harm cognizable by the U.S. antitrust scheme?-is answered by the Brunswick analysis courts have learned to apply over the past three decades. ${ }^{300}$ The second part is whether harm felt in that location is a matter of concern under the U.S. antitrust laws? After the Supreme Court decided Matsushita in 1986, the answer to the second question in any extraterritorial situation seemingly was a clear "no." In Matsushita, price fixing in Japan was not within the purview of a federal court applying U.S. antitrust laws. Matsushita is one application of the rule-recently repeated by the Empagran Court ${ }^{301}$ - that the antitrust laws exist to protect American, not foreign, commerce. ${ }^{302}$ According to the district court in de Atucha, "Congress did not contemplate recovery under the antitrust laws by an individual who traded, and was injured entirely outside of United States commerce." 303 Other courts have echoed this rules recently. ${ }^{304}$

Matsushita might be thought an easy case. It involved circumstances that undermined any arguments that U.S. antitrust policy was an appropriate vehicle to protect the plaintiffs. In Matsushita, the alleged injury was accompanied by benefits to U.S. consumers-much like the supposed harm in Brunswick Corp. ${ }^{305}$ It was thus at worst neutral, and at best,

297. Id. at 518 .

298. Id.

299. See, e.g., Turicentro, S.A. v. Am. Airlines, Inc., 303 F.3d 293, 307 (3d Cir. 2002); In re Intel Corp. Microprocessor Antitrust Litigation, 452 F. Supp. 2d 555, 563 (D. Del. 2006).

300. See 1 WALlER, supra note 84, § 9:7.

301. See supra text preceding note 146.

302. See de Atucha, 608 F. Supp. at 517 (citing Pfizer, Inc. v. Gov’t of India, 434 U.S. 308, 314 (1978), and 21 Cong. REC. 2456 (1890) (statements of Senator Sherman referring to the "interests of the United States"); 2 WALLER, supra note 19, § 13:23 ("Congress has stated that [the Sherman Act] was intended, first, to protect the competitive health of U.S. markets . . . and second . . . to protect export opportunities for American-based firms.").

303. de Atucha, 608 F. Supp. at 518. Cf. Coca-Cola Co. v. Harmar Bottling Co., No. 030737, slip op. at 1-2 (Tex. Oct. 20, 2006) (applying Texas law and holding extraterritorial relief is not available unless that relief promotes competition in Texas).

304. See Turicentro, 303 F.3d at 307; In re Intel Corp., 452 F. Supp. 2d at 563.

305. See Kruman v. Christie's Int'l PLC, 284 F.3d 384, 394 (2d Cir. 2002) ("If conduct affecting foreign markets has a substantial but beneficial effect on our markets, such conduct does not implicate the concerns of the antitrust laws."). 
competitively beneficial, in U.S. commerce. ${ }^{306}$ Empagran is a more generally applicable example of a case that fails the first step in the modified standing analysis. Unlike Matsushita, there is no basis for reading the conduct at issue in Empagran as benefiting U.S. consumers. ${ }^{307}$ The Court's narrow holding was limited to plaintiffs suffering injury with no connection to harm felt in U.S. commerce. Like the Court in Matsushita, the Empagran Court believed the justification for interference with the foreign sovereigns' regulation was "insubstantial."308

Allegations that might support standing for plaintiffs claiming wholly foreign harm would tend to establish a sufficiently proximate causal relationship-like the allegations in eMag Solutions of present intent and ability to engage in geographic arbitrage to end run foreign fixed prices. Such evidence would tend to show that the harm suffered outside the United States was inseparable from harm suffered in U.S. commerce, and if it was inseparable, it would be harm of the sort meant to be prevented.

\section{b. Directness in the Extraterritorial Context}

The Illinois Brick element requires the plaintiff to be a direct purchaser to have standing to sue for an antitrust violation. According to recent scholarship analyzing Empagran, "[i]n foreign-purchaser cases," the indirect-purchaser sort of remoteness "does not arise. Often, the foreign plaintiff purchases directly from the wrongdoers." 309 The indirectness at play is instead a function of the injury element. In the sense that a foreign purchaser's claim to antitrust injury is derivative of the claim of a purchaser in the domestic market, every foreign purchaser is an "indirect purchaser." Its right to sue depends on the existence of an effect in U.S. commerce causing harm to a different plaintiff. According to the court in de Atucha, the Illinois Brick "indirect purchaser" analysis "is not an issue" in a case dealing with foreign purchasers but lacking "innocent middlemen." 310

No need exists to write the indirect purchaser rule out of the antitrust standing analysis in the extraterritoriality context. Like the injury element, cases could arise in which the foreign plaintiff fails Illinois Brick and suffered its harm overseas as well. A foreign purchaser that buys from a foreign distributor, which in turn had paid artificially high prices due to a price-fixing cartel, fails Illinois Brick-but it may not satisfy the modified standing analysis for other reasons as well. The concerns for duplicate recovery on which Illinois Brick is based are as strong here as in the case of wholly domestic commerce.

306. Cf. Bork, supra note 74, at 133 (arguing that tie breaker cases should be resolved in favor of non-intervention); Stancil, supra note 39, at 965 (discussing the phenomenon of "Type 1 Errors" that entail holding illegal conduct that is "in fact competitively neutral or even procompetitive").

307. Likewise with the allegations in de Atucha, 608 F. Supp. at 512.

308. See supra text preceding note 146.

309. Cavanagh, supra note 146, at 1444.

310. de Atucha, 608 F. Supp. at 514. 


\section{c. Remaining Standing Factors}

The other plaintiff factor, in extraterritorial application, asks whether a plaintiff suffered harm in domestic commerce and is thus better situated than the foreign plaintiff before the court to vindicate the purposes of the U.S. antitrust laws. If there is no other plaintiff, or if the other plaintiff cannot be relied on to bring suit on its own behalf, it may be necessary to permit even a less-than-ideal foreign plaintiff to sue. ${ }^{311}$

The FTAIA permits a plaintiff suffering wholly foreign harm to rely on effects in domestic commerce to sue if there is a sufficient nexus to effects in domestic commerce. Of course, if the domestic effects have resulted in injury to other plaintiffs, those plaintiffs are available to sue to vindicate the purposes of the antitrust laws, and because their injuries more directly implicate concerns at which the U.S. antitrust scheme is directed, they are better situated to vindicate those concerns. ${ }^{312}$ The possibility of a suit also by the foreign plaintiff raises the specters of over-deterrence and, in the extreme, inverse deterrence. ${ }^{313}$ Thus, the other plaintiff factor would not overcome tenuous antitrust injury allegations under this hypothetical. But if the domestic plaintiff does not exist, or if it cannot be relied on to sue, it may be appropriate to permit a foreign plaintiff to sue over wholly foreign harm despite more tenuous antitrust injury allegations. $^{314}$ This factor shows why courts that rely solely on the question of antitrust injury to conclude a foreign purchaser lacks standing are shortsighted. ${ }^{315}$

The manageability factor primarily raises questions whether the claims before the court are so numerous, and perhaps raise such difficult issues because of the geopolitical ramifications, that they would overwhelm the U.S. court system. If so, they risk raising the costs of enforcement to the defendant and to the court system to a degree that it exceeds the benefits of enforcement. ${ }^{316}$ It is the sheer number of potential plaintiffs with

311. Cf. Pfizer Corp. v. Gov't of India, 434 U.S. 308, 315 (1981) (justifying a cause of action for foreign plaintiffs in part by the necessity of filling the deterrence purposes of the antitrust laws); Blue Shield of Va. v. McCready, 457 U.S. 465, 472-73 (1982) (reading Pfizer Corp. for the proposition that broadly interpreting the class of persons entitled to sue under Section 4 vindicates the deterrent purposes of the antitrust laws).

312. According to the de Atucha court, "individuals who traded on United States exchanges and who may have suffered injury ... a are an identifiable class of persons whose claims [can] "vindicate the public interest."' de Atucha, 608 F. Supp. at 518. In de Atucha, as in Empagran, claims by domestic purchasers were proceeding in the Southern District of New York. See id. at 518 n.21 (citing cases).

313. See supra notes 69-70 and accompanying text (discussing the "over-deterrence" concerns for chilling useful conduct through excess potential liability); supra notes 74-75 and accompanying text (discussing the paradoxical "inverse deterrence" concern that arises when excessive liability hardens cartels and makes detection more difficult).

314. See de Atucha, 608 F. Supp. at 518 (noting the importance of deterrence rationales).

315. See, e.g., Turicentro, S.A. v. Am. Airlines, Inc., 303 F.3d 293, 307 (3d Cir. 2002).

316. See Cavanagh, supra note 146, at 1443 (noting that "massive and complex damages litigation"” will involve "equally massive and complex foreign evidence") (quoting Associated Gen. Contractors of Cal. v. Cal. State Council of Carpenters, 459 U.S. 519, 545 (1983)). 
strong incentives to bring suit in U.S. antitrust courts seeking U.S. remedies that causes concern. But if the numbers of plaintiffs prove not to be massive-in other words, if only one potential plaintiff exists, and that plaintiff suffered harm in foreign commerce-the manageability concern favors permitting suit by that plaintiff. ${ }^{317}$ As in the domestic arena, manageability does not tend to encourage standing, but can discourage it if the factor's implicated.

Like manageability, the dangers of duplicate recovery and complex damages apportionment increase, as does the number of plaintiffs and the variations in economic systems in which harm is alleged to have occurred. Worldwide plaintiff classes present particular concerns due to the sheer number of potential plaintiffs. Finally, the concern for complexity is heightened when one considers the range of different economic systems worldwide in which remedies must be determined.

\section{d. Comity and Inverse Deterrence}

\section{i. Comity}

de Atucha can be seen as an example of the comity consideration at play. In de Atucha, the plaintiff's injury was incurred in a wholly foreign market regulated by its own antitrust scheme. ${ }^{318}$ The foreign sovereign at issue-Great Britain - was one of the industrialized Empagran amici with its own robust antitrust laws. ${ }^{319}$ Although under the Hartford Fire analysis comity considerations would not preclude the exercise of subject-matter jurisdiction over the conduct complained of, the comity analysis under Empagran-with its concerns for overlapping regulation and stepping on the toes of a foreign sovereign (including an inverse-deterrence concern based on a foreign amnesty program) - militates in favor of a federal court staying its hand on prudential grounds.

The comity consideration, properly undertaken (instead of being ignored on remand by the Empagran II court) might have suggested a different result as to some of the Empagran plaintiffs. Certainly concerns of overlapping regulation did not exist in the case of Ecuador, which as of today lacks its own antitrust scheme. One commentator has argued recently that Panama's antitrust regime, although it appears robust, is fledgling by comparison to that of the United States. ${ }^{320}$ Those foreign sovereigns have not publicly expressed resentment at extraterritorial antitrust regulation by the United States. And, as this Article previously has suggested, comity considerations might support regulating against harm in Ecuadorian commerce, if in doing so U.S. courts provide much needed assistance in protecting that economy from the harms caused by cartel activity.

317. Cf., e.g., de Atucha, 608 F. Supp. at 514

318. See id. (harm occurred on the London Mercantile Exchange).

319. See supra note 6 and accompanying text.

320. See Wurmnest, supra note 3, at 222-24. 
Courts faced with applying the modified prudential standing analysis should inquire whether the particular foreign sovereign's antitrust scheme-or lack thereof-would be adversely affected. Such evidence might be testimony by experts in the particular foreign scheme, or amicus participation by the U.S. Department of State or the foreign government. Evidence as to whether the particular sovereign had its own amnesty program (like Germany) and whether the U.S. program was threatened with being undermined by this action would be important.

\section{ii. Inverse Deterrence}

Application of the inverse deterrence rationale should parallel the manageability concern. If permitting plaintiffs alleging foreign harm to sue in federal court reflects a dramatic increase in the potential damage awards, government enforcement efforts are threatened. ${ }^{321}$ If permitting plaintiffs with foreign harm to sue has only a minimal increase in the total liability exposure of the defendants, the inverse deterrence rationale is not implicated. The size of the necessary increase to implicate inverse deterrence would be difficult to pinpoint exactly. Two principles may help inform the question. First, a three-times increase in the amount of liability above the level necessary for compensating victims might approximate the level that can be tolerated before standing is denied on inverse deterrence grounds. Second, close cases should be resolved in favor of denying standing rather than permitting it.

The suggested yardstick of a three-times increase in the amount of liability is based on the de-trebling provision of the Antitrust Criminal Penalty Enhancement and Reform Act, which limits damages to the compensatory level for defendants in civil suits that participated in the Department of Justice leniency program. ${ }^{322}$ Professor Page convincingly argued in 1985 that the treble damages remedy, combined with classical standing doctrine, appropriately accomplished the deterrence and compensation goals of civil antitrust enforcement. ${ }^{323}$ Professors Hovenkamp and Hylton recently have seconded the argument that treble damages make sense as a measure of deterrence of cartel activity, which (as opposed to merger activity or other, less hard-core antitrust violations) is undertaken in secret and is thus difficult to uncover. ${ }^{324}$ If treble damages appropriately serve the goal of optimizing remedies, harm to the public enforcement scheme under the inverse-deterrence rationale in a trebledamages world is not a concern. Thus, with the de-trebling provisions in the Enhancement and Reform Act, optimal remedies still would be

321. Facts bearing on the under-deterrence and inverse-deterrence rationales also would be relevant. For example, evidence that the defendant specifically aimed its conduct at the foreign market because of the lack of regulation would demonstrate a need for a U.S. court to regulate that conduct.

322. See Antitrust Criminal Penalty Enhancement and Reform Act, Pub. L. No. 108237, § 213(a), 118 Stat. 661, 666 (2004) (codified at 15 U.S.C. $\$ 1$ note (2005)).

323. See Page, supra note 22, at 1487-88. See also Hylton, supra note 65, at 60.

324. See Hovenkamp, supra note 3, at 66-68; Hylton, supra note 65, at 58-66. 
achieved under a standing rationale that allowed for "re-trebling"-permitting plaintiffs suffering wholly foreign harm to sue to vindicate that harm in U.S. courts so long as the total remedy to be awarded is not more than three times the compensatory damages due for harm suffered in U.S. commerce. ${ }^{325}$

The inverse deterrence rationale commands resolving close cases in favor of not permitting the foreign plaintiff standing to sue. This is because of the potential for a downward spiral in enforcement if excessive civil liability is permitted to interfere with public enforcement efforts. If the leniency program is frustrated when cartels are cemented under the mutually assured destruction principle, civil cases-such as the Empagran litigation, but also many other private follow-on suits-will not proceed because cartels will remain cloaked. The effect will be seriously to undermine cartel deterrence such that even treble damages liability in civil actions will under-deter. ${ }^{326}$ But the under-deterrence complaint is not realistic if standing is denied to foreign plaintiffs, because criminal enforcement and treble-damages civil suits by domestic plaintiffs remain available against all members except the first to disclose the cartel remains a possibility. ${ }^{327}$

\section{CONCLUSION}

In Empagran, the Supreme Court drew only a narrow bright-line rule. The exception to that rule, for any wholly foreign harm with a sufficient nexus to a domestic U.S. effect, has engendered substantial confusion, a state heightened by the Court's failure adequately to explain the rationale for its narrow holding or to prescribe an approach to implementing the Empagran exception. The proximate cause inquiry courts have settled on, relying heavily on the lower court's opinion on remand in Empagran, is neither procedurally workable nor doctrinally supportable.

This Article offers a solution. The well-established and regularly applied prudential antitrust standing analysis is readily imported, with modifications from Empagran, into the extraterritoriality framework. Applying standing doctrine extraterritorially, courts should examine the elements of the Associated General Contractors framework to determine whether the particular plaintiff is well situated to vindicate the purposes of the antitrust laws. Modified for extraterritorial application, the analysis includes consideration of comity and inverse-deterrence rationales that have become relevant since Empagran. The now-seven factor prudential standing analysis requires courts to consider whether the plaintiff (1) has suffered antitrust injury, (2) is a direct purchaser (if relevant), and (3) satisfies other considerations-the existence of other plaintiffs, the

325. The proposed approach may have the effect of undermining Congressional intent in enacting the Antitrust Criminal Penalty Enhancement and Reform Act.

326. See Hylton, supra note 65 , at 58 (arguing that if the probability of a successful suit is less than fifty percent, "treble damages fall below the optimal level").

327. But see Pfizer Inc. v. Gov't of India, 434 U.S. 308, 315 (1978). 
manageability of the litigation with that plaintiff before the court, the danger of complex apportionment or duplicate recovery, international comity concerns, and concerns for harm to the public enforcement regime.

Although analyzing the entire set of considerations might be new experience for courts schooled in the pre-Empagran extraterritoriality analysis, a body of common law thinking will develop to assist courts in balancing the policies of deference to foreign sovereign regulation; deference to U.S. government enforcement; concerns for protecting plaintiffs and under-deterrence; concerns for over-deterrence; and other costs and benefits associated with antitrust enforcement. 328 The standing analysis will permit courts the flexibility they require to adjust for changing understandings of those policies and other factors perhaps not yet recognized. ${ }^{329}$ As the question how to define the Empagran exception works its way through the courts, and perhaps back to the Supreme Court, ${ }^{330}$ the approach outlined here promises consistent and doctrinally correct decisions.

328. Common-law analysis is not novel to federal courts applying the U.S. antitrust laws. See generally id. at 31-37; PosNer, supra note 74, at 1 . Facility with the common law process is particularly present in the private right of action setting. See Associated Gen. Contractors of Cal. v. Cal. State Council of Carpenters, 459 U.S. 519, 531-37 (1983).

329. See generally Eastman Kodak Co. v. Image Tech. Servs., Inc., 504 U.S. 451 (1992).

330. See Diamond, supra note 12, at 830 ("Courts in various circuits already have answered this question differently since Empagran."). 